Business and Economics Research Journal
Volume 8 Number 12017
pp. $63-81$
ISSN: $1309-2448$
www.berjournal.com
DOI Number: $10.20409 /$ berj.2017126245

\title{
BİST 30 Endeks Fonlarının Seçme ve Zamanlama Yeteneği
}

\begin{abstract}
Arzu Şahin ${ }^{a}$
Öz: Yatırımcısına en az baz endeks getirisi kadar getiri sunmayı amaçlayan endeks fon yöneticilerinin, seçme ve zamanlama yeteneği sergilemesi beklenmektedir. Bu beklentiden yola çıkarak bu çalışmanın amacı, BiST 30 Endeksi fon yöneticilerinin seçme ve zamanlama yeteneğinin araştırılmasıdır. Bu nedenle, 7 adet BiST 30 endeks fonunun Ocak 2005 ve Aralık 2015 tarihleri aralığındaki günlük getirilerine Treynor-Mazuy, Henriksson-Merton ve Jensen-Alfa yöntemleri uygulanarak fon yöneticilerinin seçme ve zamanlama yetenekleri test edilmiştir. Analiz sonuçları 7 fonun hiçbirinin istatistiki açıdan önemli pozitif alfaya ve ilgili zamanlama katsayısına sahip olmadığını ve dolayısıyla BiST 30 endeksi fon yöneticilerinin seçme ve zamanlama yeteneğinin bulunmadığını göstermektedir.
\end{abstract}

Anahtar Sözcükler: Endeks Yatırım Fonu, Seçicilik, Zamanlama, Kuadratik Regresyon, Kukla Değişkenli Regresyon

JEL Sınıflandırması: G11, C32

\section{Selection and Market Timing Ability of BIST 30 Indexes Funds}

\begin{abstract}
The index fund managers, who aim to offer the investor at least as much as the return of the base index, are expected to exhibit selection and timing ability. Based on this expectation the aim of this study is to investigate the selection and timing ability of BIST 30 indexes funds. Therefore, the selection and timing ability of fund managers were tested by applying Treynor-Mazuy, Henriksson-Merton and Jensen-Alpha methods to the daily returns of 7 BIST 30 indexes funds between the time period of January 2005 and December 2015. The analysis findings indicate that none of the 7 funds had statistically significant positive alphas and related timing coefficients so BIST 30 index funds managers did not have selective ability and market timing ability.
\end{abstract}

Keywords: Index Mutual Funds, Selection, Timing, Quadratic Regression, Dummy Variable Regression

JEL Classification: G11, C32

${ }^{a}$ Assist. Prof., Adana Science and Technology University, Faculty of Business, International Trade and Finance Department, Adana Turkiye, asahin@adanabtu.edu.tr 


\section{Giriş}

Yatırım fonlarının performansları, fon yöneticilerinin tecrübe, yetenek ve algıları gibi değişkenlere duyarlıdır. Yatırım fonu yöneticileri, doğru hisse senetlerini seçerek ve/veya fonun riskini pazarın yönüne göre ayarlayarak fon performansını artırabilmektedir. Yöneticilerin birinci tür davranışı seçicilik yeteneğinin, ikinci tür davranışı ise zamanlama yeteneğinin göstergesi olarak düşünülmektedir.

Seçicilik yeteneği olan yöneticiler, düşük fiyatlanmış firmaları belirleyerek ve iyi tahminde bulunarak getiri elde etmektedir. Zamanlama yapan yöneticiler, fonun risk düzeyini hisse senedi piyasasındaki gelişim öngörülerine göre değiştirirler. Pazarda düşme öngördükleri zaman portföy riskini/betasını düşürürler veya tahvil/nakit yüzdesini artırırlar. Pazar artışı beklentileri olduğunda ise portföy betasını veya riskli hisse oranını artrarak pazar hareketinden avantaj sağlarlar.

Fon yöneticilerinin seçicilik ve zamanlama yeteneklerinin risk faktörü de dikkate alınarak ölçülmesi, fon performansına açıklama getirebilmektedir. Yatııı fonu performansı hakkında yapılan öncül çalışmalar (Treynor ve Mazuy, 1966; Jensen, 1968; Grinblatt ve Titman, 1994; Cai, Chan ve Yamada, 1997) ve son yıllarda yapılan çalışmalar (Bialkowskia ve Ottenb, 2011; Christensen, 2013; Dhar ve Mandal, 2014; Tan,2015), fon yöneticilerinin genellikle yeterli düzeyde seçicilik ve zamanlama yeteneğine sahip olmadıklarını ortaya koymuştur.

A tipi yatırım fonları ve emeklilik fonlarının seçicilik ve zamanlama yeteneklerine yoğunlaşan Türkiye'de yapılan çalışmaların (Arslan, 2005; Gökgöz, 2007; Altnntaş, 2008; Korkmaz ve Uygurtürk, 2007; Korkmaz ve Uygurtürk, 2009) bulguları da özellikle pazar zamanlaması açısından uluslararası literatür ile uyumludur.

Bu çalışmada, endeks fonlarının seçicilik ve zamanlama yeteneği üzerinde durulmuştur. Endeks fon, toplam değerinin en az \%80'i devamlı olarak baz alınan endeks kapsamındaki menkul kıymetlere yatıılan ve baz alınan endeks ile korelasyonu \%90 olması gereken fonlardır. Endeks fonları, yatırımcısına endeks getirisine paralel ve/veya minimum endeks getirisi kadar getiri sunmayı amaçlamaktadır. Bu amaca ulaşmak için endeks fon yöneticisinin de seçme ve zamanlama yeteneği göstermesi beklenmektedir.

Endeks fon ile baz alınan endeks değeri korelasyonunun minimum \%90 olması şart, endeks fon yöneticisinin menkul kıymet seçimin ve portföyün riskini pazar riskine göre ayarlama davranışına sınırlama getirmektedir. Buna rağmen endeks fonları, borsa yatırım fonlarının aksine menkul kıymetlere, baz endeks ile aynı oranda yatırım yapmak zorunda değildir. Endeks fon yöneticileri, baz endeksten yüksek performans gösterecek kadar yatırım oranı seçme serbestisine sahiptir. Ayrıca, payların sektör veya firma dağılımını pazar öngörülerine göre değiştirerek yatırımcı getirisini doğru zamanlama ile artırma yönünde hareket alanları bulunmaktadır.

Endeks fon yöneticilerin de seçme ve zamanlama yeteneği sergilemesi beklentisinden yola çıkarak bu çalışmada, BiST 30 Endeksi fon yöneticilerinde seçme ve zamanlama yeteneğinin varlığı incelenmiştir. Bu kapsamda, 7 adet BIST 30 endeks yatırım fonunun 2005 Ocak ve 2015 Aralık dönemi arasında günlük getirileri analiz edilmiştir. Günlük getirilere uygulanan Treynor-Mazuy (1966) ve Henriksson-Merton (1981) modelleri ile fonların zamanlama yeteneği ölçülürken, Jensen-Alfa (1968) yöntemi ile seçicilik yeteneği test edilmiştir.

Fon performans sunum raporlarına göre incelenen 7 adet BiST 30 endeks fonunun getirisi, birçok dönemde karşılaştırma ölçütünden düşüktür. Ayrıca, bazı dönemlerde fon getirilerinin birbirinden oldukça farklılaştı̆ı izlenmiştir. Aktif yönetilen bu endeks fonlarının fon yönetim ücreti, toplam faaliyet giderleri içinde en yüksek paya sahip olan giderdir. Diğer yatırım fonları gibi yatırımcısına fon yönetim ücreti yansıtan ve en az baz endeks getirisi kadar getiri sunmayı amaçlayan ancak yıllık bazda yatırımcısına düşük getiri sunan BisT 30 endeks fonlarının yönetim etkinliğinin değerlendirilmesi gerektiği düşünülmektedir. Buna karşılık, endeks fonlarının performansını, performansının belirleyicilerini, seçme ve zamanlama yeteneğini araştırarak yönetim etkinliğini değerlendiren yeterli araştırmaya rastlanmamıştır. Bu kapsamda, bu çalışmanın literatüre başlıca katkısının, endeks fon yönetim etkinliğinin incelenmesi olduğu söylenebilir. 
Beş bölümden oluşan bu çalışmanın ilk üç bölümünü; çalışmanın amaç ve kapsamını içeren giriş bölümü, seçme ve zamanlama yeteneğinin ölçümünde kullanılan yöntemlerin açıklandığı ikinci bölüm, literatür araştırmasının özetlendiği üçüncü bölüm oluşturmaktadır. İzleyen bölümde araştırmanın yöntemi, veri seti tanıtılarak analiz bulguları tartışımış ve son olarak araştırmanın genel değerlendirmesi yapılmıştır.

\section{Seçme ve Zamanlama Yeteneğinin Ölçülmesi}

Farklı riskteki fonların performans karşılaştırması, riske göre düzeltilen getirilerle yapılmaktadır. Riske göre düzeltilmiş performans ölçümleri, bir birim riske göre getiriyi değerlendiren ölçütler ve farklılaşan getiri ölçümleri olarak iki kategoriye ayrılabilir. Bir birim riske göre getiriyi ölçen iki alternatif yöntem; Sharpe Endeksi ve Treynor Endeksidir. Farklılaşan getiri ise Jensen-Alfası olarak ifade edilen yöntem ile ölçülmektedir (Elton, Gruber, Brown ve Goetzmann, 2011: 629, Farrel, 1997: 517-522). Jensen-Alfası (1968), aynı zamanda yöneticinin doğru menkul kıymeti seçme yeteneğini ölçmektedir. Bu ölçümler, tek bir faktörü (pazar riskini) dikkate alan tek parametreli ölçüm yöntemleridir.

Jensen-Alfası modelinde alfa, söz konusu varlıktan elde edilecek artık regresyon tahminidir. Pozitif alfa değerine sahip portföyler, kendi sistematik risk düzeyine uygun getiriden daha fazla ortalama getiri elde etmişlerdir. Bu nedenle alfa kesim noktası, yatıım performansının ölçümünde kullanılmakta ve yöneticinin doğru menkul kıymet seçme yeteneğini ortaya koymaktadır (Karan, 2011, s. 681-682).

Pazar zamanlamasını ölçmenin bir yolu, fon getirisinin pazar getirisine göre durumuna bakmaktır. Fon yöneticisi, fon betasını pazar portföyündeki değişimlere göre değiştirmek isterse fon performansı ile pazar performansı arasındaki doğrusal ilişkinin yapısı değişecektir. Bu ilişkiden faydalanan Treynor ve Mazuy (1966), zamanlama yeteneğini test etmek için bir kuadratik regresyon modeli geliştirmiştir. Hendriksson ve Merton (1981) tarafindan hazırlanan kukla değişkenli diğer bir model ile de yöneticilerin seçme ve zamanlama yetenekleri ölçülmektedir (Karan, 2011, s: 683- 684). Bu modeller, pazar getirisine pazar getirisinin karesi ve kukla değişken eklediklerinden dolayı çok kriterli modellerdir.

\subsection{Jensen-Alfası}

Jensen (1968), portföy yöneticisinin tahmin yeteneğini ölçmeye çalışmıştır. Bu yetenek, belirli bir risk seviyesinde yatırımcıdan daha iyi tahminde bulunarak getiri elde etme yeteneğidir. Ayrıca, önceki performans ölçümlerinden farklı olarak, örnekleme hatalarını ölçmek ve bu hatalarının istatistiki önemini belirlemek istemiştir (Jensen, 1968: 389-390).

Yöneticinin seçme yeteneğinin ölçülmesinde kullanılan Jensen ölçütü, Sermaye Varlıkları Fiyatlama Modeli (SVFM)'ne göre hazırlanmıştr. Bu yöntemin amacı, gerçekleşen riske göre bir portföyün beklenen getirisini hesaplayarak o dönemdeki gerçekleşen getirisi ile karşılaştırmaktır. Gerçek getiri ile beklenen getiri arasındaki fark "alfa" terimi olarak ifade edilmekte olup alfa terimini elde etmenin bir yolu, tarihi verileri kullanarak 1. eşitlikte yer alan regresyondan faydalanmaktır. Bu yaklaşım ile fon ile pazar performansı karşılaştırılarak fonun, pazara göre elde edeceği performansın istatistiksel önemi değerlendirilmektedir (Karan, 2011: 679-681).

$$
\left(R_{i t}-R_{f t}\right)=a_{i}+b_{i}\left(R_{m t}-R_{f t}\right)+e_{i}
$$

$R_{i t,} \quad t$ döneminde i fonunun getirisi

$R_{m t}, t$ döneminde pazar indeksinin getirisi

$\mathrm{R}_{\mathrm{ft}}$, risksiz varlık getirisi

$a_{i}$, alfa (Jensen ölçütü)

$b_{i}$, portföyün betası

$e_{i}$, hata terimi 
Portföy yöneticisi veya menkul kıymet analistinin menkul kıymet fiyatlarını tahmin edebilme yeteneği varsa, 1. eşitlikte alfa kesim noktası pozitif olacaktır. Alfa, yöneticinin sadece menkul kıymet fiyatlarını tahmin yeteneğinin etkisiyle portföyde meydana gelen ortalama getiri artş̧ını ifade etmektedir. Rassal seçilen portföylerde alfa, sıfir değerini almaktadır. Bu durumda yönetici, rassal seçim politikası kadar iyi seçim yapamıyorsa alfa negatif olacaktır. Rassal seçimden daha kötü seçim yapmak zor gibi görünse de bu tür sonuçlarla karşılaşılmaktadır (Jensen, 1968: 394).

\subsection{Treynor-Mazuy Kuadratik Regresyon Modeli}

Sistematik riskin ölçütü olan beta katsayısı $(\beta)$, menkul kıymet getirileri ve pazar portföyü getirilerinin gelişimini en iyi temsil eden ve karakteristik doğrusu olarak tanımlanan doğrunun eğimine eşittir (Canbaş ve Doğukanlı, 2012: 517). Zamanlama yeteneğini analiz etmek için fon performansı ile pazar performansı arasındaki doğrusal ilişkiyi gösteren karakteristik doğrusunun yapısından faydalanılmaktadır.

Sadece hisse seçimine odaklanan ve pazar zamanlaması yapmayan bir fonun ortalama betası sabittir. Fon getirisi ile pazar getirisi ilişkisini gösteren karakteristik doğrusu ise Şekil 1 ile görüldüğü gibi doğrusal bir ilişkiyi yansıttr (Elton vd., 2011: 539-651; Farrel, 1997: 529).

Şekil 1. Pazar Zamanlaması Yapmayan Fon Getirisi ve Pazar Getirisi ilişskisi

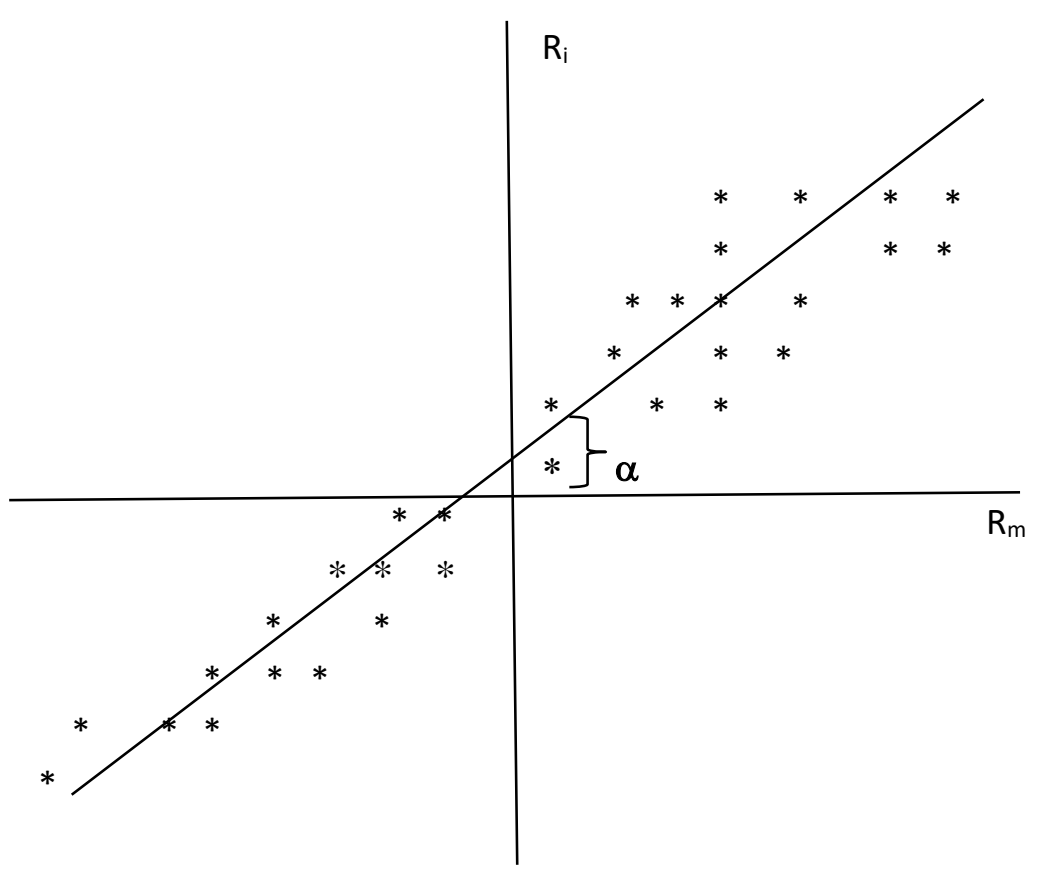

Kaynak: Farrel, 1997: 529.

Pazar tahmininde başarılı olan fon yöneticileri, hisse senedi pazarının genel yükseliş ve düşüşlerini öngörerek portföy birleşimini bu öngörüye göre düzenlemektedir. Buna göre yöneticiler, pazar düşüşü öngörürse portföy karmasını, betası daha düşük olan menkul kıymetlere kaydırırken, pazar yükselişi tahmini ile portföy birleşimini daha riskli menkul kıymetlere kaydırırlar. Bu hareketler, portföy betasında bir değişime yol açar (Treynor ve Mazuy, 1966: 132).

Treynor ve Mazuy (1966), "fonun sistematik riski, pazar performansının iyi olduğu yıllarda kötü olan yıllara göre daha yüksek mi?" sorusuna cevap arayarak yatırım fonu yöneticilerinin pazar tahmin yeteneğini test etmiş̧ir. Başarılı pazar tahmini ile hissedar gelirini artırma yeteneği gösteren yöneticiler, fonun sistematik riskini değiştirerek karakteristik doğrusunu yukarı doğru konkav hale getirmektedir (Treynor ve Mazuy, 1966: 132-134). Başarılı zamanlama yapılan bir fona ait karakteristik doğrusunun eğimi, Şekil 2'de gösterilen eğriye benzeyecektir. Ayrıca, Şekil 1 ve Şekil 2'de yer alan alfa $(\alpha)$, seçme yeteneğini ifade etmektedir. 
Şekil 2. Pazar Zamanlaması Yapan Fon Getirisi ve Pazar Getirisi Ilişkisi

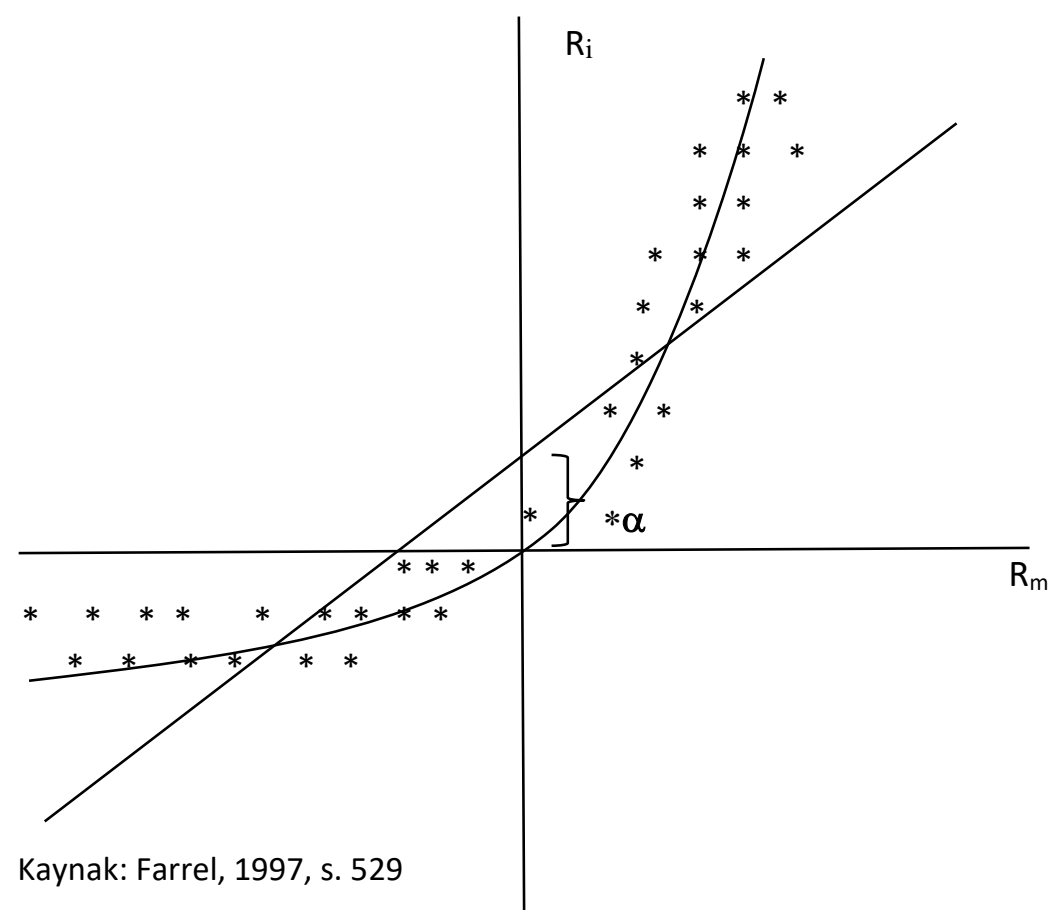

Başarılı zamanlama yapılması durumunda pazar getiri artışı, betası artırılan fonun performansını yükseltecektir. Benzer şekilde yönetici, pazar getirisinde azalış öngörürse fonun betasını düşürecek ve fonun getiri azalışı, normal betası ile katlanacağından daha az olacaktır. Düşük ve yüksek pazar performansları için normal ilişkinin üzerinde olan fon getirileri, başarılı zamanlama durumunda dağınık noktalara bir kıvrım/eğrilik vermektedir. Bu durum Şekil 2 ile örneklendirilmiştir (Elton vd., 2011: 649-650).

Treynor ve Mazuy, Şekil 2 ile örneklendirilen kuadratik eğriliği test etmek için bir kuadratik ifade ekleyerek 2. eşitlikte verilen çoklu regresyon modelini elde etmiştir. Bu model, değişen betanın yol açttğı eğrinin matematiksel ifadesi olup yöneticinin zamanlama yeteneğinin ölçüm yöntemidir.

$$
\left(R_{i t}-R_{f t}\right)=a_{i}+b_{i}\left(R_{m t}-R_{f t}\right)+c_{i}\left(R_{m t}-R_{f t}\right)^{2}+e_{i}
$$

$R_{\text {it }}, \quad t$ döneminde $i$ fonunun getirisi

$R_{m t}, t$ döneminde pazar indeksinin getirisi

$\mathrm{R}_{\mathrm{ft}}$, risksiz varlık getirisi

$e_{i}$, hata terimi getirisi

$?_{\mathrm{i}}, b_{\mathrm{i}}$ ve $c_{\mathrm{i}}$, sabitler

Eşitlik 2'de fon getirisi ve pazar getirisi ilişkisi düz doğru şeklinde ise kareli terimin katsayısı olan $c_{i}$, sıfir değerini alır. Getiri ilişkisi eğri şeklinde ise $c_{i}$ pozitif olur. Burada $c_{i}$, fonun zamanlama yeteneğinin ölçütüdür (Elton vd., 2011: 650). Ayrıca $\alpha_{i}$,zamana göre düzeltilen alfa olup fon yöneticisinin zamana göre düzeltilen seçme yeteneğini ifade etmektedir (Tan, 2015: 51).

\subsection{Henriksson - Merton Kukla Değişkenli Regresyon Modeli}

Henriksson ve Merton (1981) tarafindan geliştirilen bir model ile de bir portföyün değişen betası, diğer bir ifadeyle zamanlama yeteneği ölçülmektedir. Yazarlar, yaptıkları çalışmada pazar getirisinin $\left(R_{m t}-\right.$ $R_{f t}$ ) büyüklüğünü değil de işaretini tahmin ederek pazar zamanlama yeteneğini ölçen bir model geliştirmişlerdir (Henriksson ve Merton, 1981: 531). 
Henriksson-Merton modeline temel oluşturan fon-pazar getiri ilişkisi, 3. Şekil ile gösterilmiştir. Bu modelde fonun betası, pazarın yükselme beklentisinin olduğu durumlarda yüksek değer, pazarın düşme beklentisi olduğu durumlarda düşük değer almaktadır (Bodie, Kane ve Marcus, 2001: 826). Bir başka ifade ile başarılı pazar zamanlaması yapan bir yönetici, yüksek performans gösteren pazarda yüksek betaya, düşük performans gösteren pazarda düşük betaya sahip olmalıdır. Bu ilişki, iki farklı karakteristik doğrusu ile ifade edilmektedir. Pazar getirisinin yüksek olduğu durumu ifade eden karakteristik doğrusunun eğimi, düşük getirili pazar için uygun olan doğrunun eğiminden yüksektir (Elton vd. 2011: 650-651; Farrel, 1997: 530-531).

Şekil 3. Kukla Değişkenli Regresyon Modelinde Fon - Pazar Getirisi İlişkisi

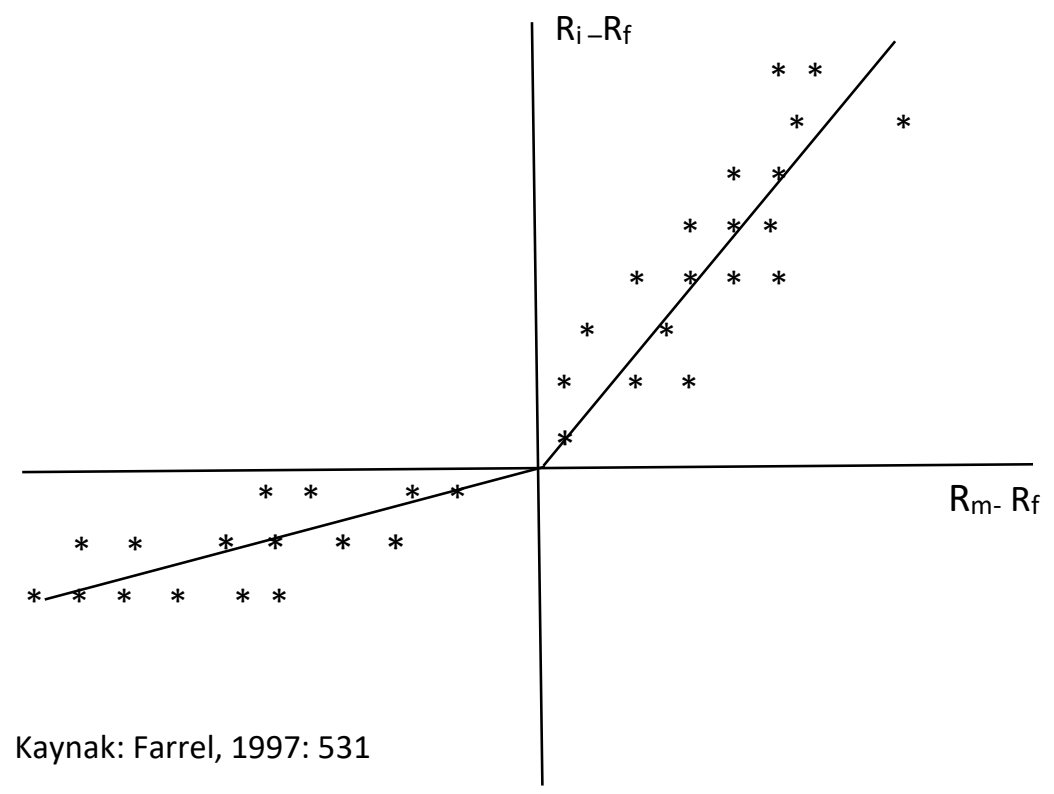

Şekil 3 ile gösterilen fon-pazar getiri ilişkisi, Henriksson ve Merton (1981) tarafindan normal regresyon eşitliğine bir kukla değişken eklenerek oluşturulan 3 nolu regresyon eşitliği ile ifade edilmektedir.

$$
\begin{gathered}
\left(R_{i t}-R_{f t}\right)=a_{i}+b_{i}\left(R_{m t}-R_{f t}\right)+c_{i} D\left(R_{m t}-R_{f t}\right)+e_{i} \\
\mathrm{D}=0, R_{m t}-R_{f t} \geq 0 \text {, yüksek pazar } \\
\mathrm{D}=-1, R_{m t}-R_{f t}<0 \text {, düşük pazar }
\end{gathered}
$$

Modelde $b_{i}$, yüksek pazar betasını ( $D=0$ iken), $b_{i}-c_{i}$, düşük pazar betasını ( $D=-1$ iken), $c_{i}$, ise yüksek pazar betası ile düşük pazar betası arasındaki farkı ifade etmektedir. İstatistiksel olarak anlamlı ve pozitif $\mathrm{c}_{\mathrm{i}}$, başarılı pazar zamanlamasının göstergesidir (Elton vd., 2011: 651). Eşitlik 3 ile kurulan hipoteze göre $a_{i}=0$ olduğunda yöneticinin seçme yeteneği, $\mathrm{c}_{\mathrm{i}}=0$ olduğunda ise zamanlama yeteneği yoktur. İstatistiksel olarak anlamlı ve pozitif $a_{i}$ ve $c_{i}$, yöneticinin başarılı seçme ve zamanlama yeteneğinin varlığına işaret etmektedir (Karan, 2011: 684).

\section{Literatür Taraması}

Yöneticilerin doğru seçim ve başarılı zamanlama yeteneğinin bulunmadığı sonucuna varan çalışmalar olduğu gibi yöneticilerin başarısına işaret eden çalışmalar da bulunmaktadır. Bu alanda yapılan çalışmalar, birbiri ile çelişen sonuçlar verse de yatırım fonlarının ortalamada pazar performansını geçemediği ve pazar zamanlaması yapamadığı sonucuna varan çalışmaların çoğunlukta olduğu söylenebilmektedir.

\subsection{Uluslararası Çalışmalar}

$A B D$ yatırım fonu piyasasında gerçekleştirilen teorik ve uygulamalı öncül çalışmalarla, fon performans ölçümünde kullanılan temel modeller geliştirilmiştir. Treynor (1965), 1953-1962 yılları arasında aktif yönetilen 20 fon yöneticisinin performansını, fonun sistematik riskini kullanarak ölçmeyi önermiştir. Sharpe 
(1966), 1954-1963 döneminde 34 yatırım fonunun performansını toplam varyans (standart sapma) kullanarak ölçmüştür. Önerdiği ölçütü Treynor ölçütü ile karşılaştran Sharpe, iyi çeşitlendirilen bir fonun performans tahmininde betanın, toplam varyansa göre daha iyi sonuç verdiğini belirtmiştir. Horowitz (1966), 27 fonluk bir örneklem ile fonların amaçlarındaki farklııık dahil edildiği takdirde Sharpe oranının, farklııkları açıklama yeteneğinin düştüğünü savunmuştur.

Jensen (1968), 1945-1964 döneminde ABD'de 115 yatırım fonunun performansını inceleyerek portföy yöneticisinin seçme yeteneğini ölçen bir yöntem geliştirmiştir. Fonların pazardan üstün performans göstermediğini ortaya koyan çalışma bulguları ile menkul kıymet fiyatlarının yeterince iyi tahmin edilmediği ve seçme yeteneğinin zayıf olduğu sonucuna varılmıştır. Treynor ve Mazuy (1966), geliştirdikleri kuadratik regresyon modelini 1953-1962 yıllarında ABD'nin 57 fonuna uygulayarak, yatırım fonu yatrımcılarının genel pazar hareketlerinden gelir elde edemediğini ortaya koymuştur. Henriksson ve Merton (1981) teorik çalışmasında, zamanlama yeteneğini ölçmek amacıyla kukla değişkenli regresyon modelini önermiştir.

ABD yatırım fonu piyasasının performansını ölçmeye yönelik olarak 1970-2000 yılları arasında gerçekleştirilen ve bu çalışmada incelenen diğer çalışmaların bulguları farklılık göstermektedir. Yatırım fonlarının, pazardan üstün performans sergilediği sonucuna varan çalışmalar (McDonald, 1973; Grinblatt ve Titman, 1989; Ippolito, 1989), yanı sıra pazardan düşük performans sergilediğini gösteren çalışmalar (Kim, 1978; Grinblatt ve Titman, 1994) bulunmaktadır.

McDonald (1973), New York Borsasının en eski 8 Fransız yatırım fonunun 1964-1969 dönemi getiri performansını, Sharpe, Treynor ve Jensen yöntemleri ile incelemiştir. Grinblatt ve Titman (1989), 1975-1984 döneminde 274 adet ve 157 adet fon içeren iki örnekleme pozitif dönem ağırlıklı Jensen ölçümü uygulamıştır. Ippolito (1989), 1965-1984 yıllarında 143 ABD yatırım fonunun performansını Jensen alfası ile incelemiştir. Her üç çalışma sonucunda da aktif yönetilen fonların üstün performans sergilediği ortaya çıkmıştır.

Kim (1978), 1969-1975 yıllarında 138 yatırım fonunun performansını, ağılıklı endeks gösterge portföyü yaklaşımı ile değerlendirmiştir. Grinblatt ve Titman (1994), 279 aktif ve 109 pasif yatırım fonu üzerinde Jensen ölçümü, Grinblatt ve Titman (1989)'ın pozitif dönem ağırlıklı Jensen ölçümü ve TreynorMazuy modelimi test etmiştir. Her iki çalışma sonucu da fonların pazardan düşük performans gösterdiğini ortaya çıkarmıştır.

Seçme ve zamanlama yeteneği konusunda benzer bulgular sunan Grinblatt ve Titman (1994) ve Daniel, Grinblatt, Titman ve Wermers (1997), ABD fon yöneticilerinin seçme yeteneğinin bulunduğu ancak başarılı zamanlama yapamadıklarını göstermiştir. Daniel vd. (1997), 2.500 hisse senedi fonunun 1974-1994 yılları verilerine Jensen ölçümü ve pozitif dönem ağırlıklı Jensen ölçümlerini uygulamıştır.

2000 'li yıllara kadar ABD yatırım fonlarının performansını inceleyen araştırmacılardan Carıson (1970) ve Lehmann ve Modest (1987), performansın gösterge portföye duyarlı olduğu sonucuna varmıştır. Carlson (1970), 82 hisse senedi yatırım fonunun 1948-1967 dönemi performansını Sharpe, Treynor ve Jensen modellerini temel alarak incelemiştir. Lehmann ve Modest (1987), 1968-1982 döneminde 130 yatırım fonuna Jensen modelini uygulamıştır.

Blake, Elton ve Gruber (1993), doğrusal ve doğrusal olmayan modeller ile incelediği 1974-1988 yılları arasında 46 adet, 1987-1991 yılları arasında 223 adet ABD tahvil yatırım fonunun performansını, gösterge endekslerden düşük değerlendirmiştir. Gallo, Lockwood ve Swanson (1997) ve Detzler (1999) ise ABD merkezli uluslararası tahvil yatırım fonlarının düşük performans gösterdiği bulgularını elde eden çalışmalar yapmıştır. Gallo, Lockwood ve Swanson (1997), 1988-1994 dönemi için tekli ve çoklu indeks göstergelerini kullanarak, Detzler (1999) ise 1988-1995 döneminde 19 global ve uluslararası tahvil yatırım fonuna Jensen ve pozitif dönem ağırlıklı Jensen yöntemlerini uygulayarak benzer sonuçlara varmıştır.

Yatırım fonuna yatırılan sermaye miktarının, fonun geçmiş performansı ile ilişkisi olduğunu ve bu ilişkinin yöneticilerin yeteneklerinden etkilendiğini savunan Berk ve Green (2004), aktif portföy yönetimi için yeni bir model oluşturmuştur. Elton, Gruber ve Blake (1996), 1976 yılına kadar olan fonlar arasından belirlenen 188 fonluk örneklem üzerinde, yaşam eğiliminin etkisini incelemiş ve yaşam eğiliminin büyüklüğünü hesaplayarak bu konuda gösterge sağlamıştır. 
Bu çalışmada incelenen ABD dışında 7 farklı ülkenin yatırım fonu performansını araştıran çalışmaların bulguları, yatırım fonlarının düşük performans gösterdiği, seçme ve zamanlama yeteneklerinin bulunmadığını yönündedir.

Cai vd., (1997), 1981-1992 döneminde Japonya'da 800 adet hisse senedi yatrım fonu performansını Jensen ölçümü ve pozitif dönem ağırlıklı Jensen ölçümü ile analiz etmiştir. Dahlquist, Engstrom ve Soderlind (2000), İsveç pazarında 1992-1997 yılları arasında 126 hisse senedi fonu ve 42 tahvil fonu performansını, zamana göre değişen betalara izin veren Jensen alfası ile ölçmüştür. Stotz (2007), 1990-2005 yıllarında Almanya'da 129 hisse senedi yatırım fonuna, Bialkowskia ve Ottenb (2011) ise 2000-2008 yılları arasında Polonya pazarında yer alan 140 yatırım fonuna Carhart (1997) 4 faktörlü varlık fiyatlama modeli uygulamıştır. Bu dört çalışmada da fon performansının düşük olduğu sonucuna varılmıştır.

Christensen (2013), 2001-2010 yıllarında faal olan 44 Danimarka yatırım fonunun, Tan (2015) ise 2009-2014 döneminde Güney Afrika'nın 10 adet hisse senedi fonunun seçicilik yeteneğini, Jensen-Alfası ile ölçerek, fon yöneticilerinin seçicilik yeteneği açısından yeterli olmadığını ortaya çıkarmıştır.

Stotz (2007), Tan (2015) ve Dhar ve Mandal (2014), fon yöneticilerinin pazar zamanlamasında başarılı olmadığını sonucuna, Treynor-Mazuy ve Henrinkson-Merton yöntemlerini birlikte kullanarak ulaşmıştr. Christensen (2013) ise sadece Treynor-Mazuy yönetimini kullanarak Danimarka pazarı için benzer sonuca varmıştır. Dhar ve Mandal (2014), Hindistan'ın 80 yatırım fonunu, 2000 - 2012 döneminde incelemiştir.

Bauer, Derwall ve Otten (2007), 1994-2003 yılları arasında Kanada pazarında yer alan 8 etik (sosyal sorumlu) yatırım fonunun performansını, 267 geleneksel yatırım fonu ile karşıllaştırmıştr. Jensen alfa, Carhart (1997) ve Ferson ve Schadt (1996) yöntemleri uygulanarak etik fon performansının, geleneksel fon performansından önemli derecede farklı olmadı̆̆ı bulunmuştur.

\subsection{Türkiye'de Yapılan Çalışmalar}

Türk yatırım fonlarının performansının değerlendirilmesinde, tek parametreli ölçüm yöntemleri olarak da ifade edilen geleneksel performans değerleme yöntemleri olan; Treynor, Sharpe, Jensen, Sotino, $\mathrm{M}^{2}$, Fama ve Değerleme oranlarından faydalanılmıştır. Bu çalışmada incelenen araştırmacılar (Arslan, 2005; Gökgöz, 2007; Korkmaz ve Uygurtürk, 2007; Korkmaz ve Uygurtürk, 2009; Altıntaş, 2008; Samırkaş ve Düzakın, 2012; Yolsal, 2012), analizlerinde geleneksel ölçüm yöntemlerinin birkaçını kullanmıştır.

Emeklilik yatıım fonlarının performansını araştıran Gökgöz (2007), Korkmaz ve Uygurtürk (2007) ve Altıntaş (2008), farklı sonuçlara ulaşmıştır. Gökgöz (2007), 2003-2006 yılları arasında faal olan 9 fonun üstün performans sergilediğini, Korkmaz ve Uygurtürk (2007) ise 2004-2006 tarihleri arasında 46 fonun üstün performans göstermediği yönünde bulgular elde etmiştir. Altıntaş (2008), 2004-2006 yıllarında 36 emeklilik yatırım fonunun performansının, kullanılan ölçüm yöntemine duyarlı olduğunu ifade etmiştir.

Arslan (2005)'ın incelediği 45 A tipi yatırım fonunun 2002-2005 yılları arasında performansı, ölçüm yöntemine göre farklılık göstermiştir. Korkmaz ve Uygurtürk (2009), 2006-2009 döneminde 12 adet A Tipi, emeklilik ve borsa yatırım fonunun performansını karşılaştırdığı çalışmasında, düşük fon performansı sonucuna ulaşmıştır. Samırkaş ve Düzakın (2012), 2000-2010 yılları arasında A ve B tipi fon performansını karşılaştırarak, A tipi yatıım fonlarının daha fazla yılda başarılı olduğunu bulmuştur. Yolsal (2012), bankalar ve aracı kurumlar tarafindan ihraç edilen fon yöneticilerinin performansını karşılaştırmıştır. Çalışmada, 20 adet A tipi yatırım fonunun 2009-2012 yılları performansının, aracı kurumların ihraç ettiği fonların performansından daha düşük olduğu ortaya çıkmıştır.

Jensen alfası, Altıntaş (2008), Korkmaz ve Uygurtürk (2009) ve Yolsal (2012)'ın çalışmalarında seçicilik yeteneği olarak yorumlanmıştır. Altıntaş (2008) ve Korkmaz ve Uygurtürk (2009)'ün çalışma bulguları, fon yöneticilerinin seçme kabiliyetlerinin olmadığını göstermiştir. Yolsal (2012), aracı kurum fonlarının seçme yeteneğinin banka fonlarından düşük olduğunu göstermiştir. Gökgöz (2007) ve Karatepe ve Gökgöz (2007), incelediği fonların Treynor-Mazuy modelinin alfa değerine göre, menkul kıymet seçiminde başarılı olduğu sonucuna varmıştır. 
Türk yatırım fonlarının zamanlama yeteneğinin ölçümünde Treynor-Mazuy kuadratik regresyon modeli ve Henrinkson-Merton kukla değişkenli regresyon modellerinin kullanıldığı görülmektedir. Her iki yöntemi birlikte kullanarak zamanlama kabiliyetini ölçen Korkmaz ve Uygurtürk (2007), Korkmaz ve Uygurtürk (2009) ve Altıntaş (2008) yöneticilerinin piyasa zamanlamasında başarı gösteremedikleri sonucunu varmıştır. Yolsal (2012), aracı kurum fonlarının zamanlama kabiliyetlerinin daha düşük olduğunu belirtmiştir.

Sadece Treynor-Mazuy yöntemini kullanan Arslan (2005) ve Gökgöz (2007), yöneticilerinin zamanlama çabalarının yetersiz olduğunu belirtmiştir. Karatepe ve Gökgöz (2007) ise 2001-2002 yıllarında aktif yönetilen 15 adet A-Tipi Karma hisse senedi fonunun Treynor-Mazuy modeline göre zamanlama yeteneği gösterdiğini ancak performansın devamlı olmadığını ortaya koymuştur.

Apak ve Taşçıan (2009), 60 adet emeklilik yatırım fonunun 2004-2008 dönemi performanslarını Morningstar yıldız derecelendirme sistemi kullanarak değerlendirmiştir. Bu sisteme göre fonda etkin bir portföy yönetimi uygulanmadığı ve fon getirisinin çoğunlukla hazine bonosu getirisinden düşük olduğu ifade edilmektedir. Alptekin ve Şıklar (2009) çalışmasında, 12 adet emeklilik yatırım fonunun 2007- 2008 dönemindeki performansını TOPSIS metoduyla değerlendirilmiştir. Sarıtaş (2005) ve Özek (2014) fon performansının belirleyicilerine odaklanmıştır. Alper ve Ertan (2008) ise yatırım fonu yatırımcı davranışını incelemiştir.

\section{Metodoloji}

Bu bölümde çalışma döneminde analize dahil edilen BiST 30 endeks fonlarının zamanlama ve seçicilik yeteneği gösterip göstermediği istatistiksel yöntemlerle ortaya konulmaya çalışılacaktır.

\subsection{Analiz Yöntemi}

Türk yatırım fonu pazarında yer alan 7 adet BiST 30 endeks fonundan oluşan örneklemin fon yöneticilerinin zamanlama yeteneği, iki temel model olan Treynor-Mazuy (1966) ve Henriksson-Merton (1981) modelleri ile ölçülmüştür. Seçme yeteneği için Jensen-Alfası (1968) hesaplanmıştır.

\subsection{Analiz Verileri}

Analizde veri olarak, BIST 30 Endeks yatırım fonları, devlet iç borçlanma senetleri, BiST 30 Endeksi kullanılmıştır. Analizde kullanılan verilerin bir aylık örneği Ek.1'de yer almaktadır.

\subsubsection{Fon Getirisi}

$\mathrm{Bu}$ analize, çalışma tarihi itibari ile faal olan 7 adet BiST 30 Endeksi Hisse Senedi Yatırım Fonunun 04.03.2005 ve 31.12.2015 tarihleri arasındaki günlük getirileri dahil edilmiştir. Fonların birim pay değerleri ile günlük basit getirileri hesaplanmıştır.

Dönem getirisi, basit bir ifade ile bir yatırıma yapılan her bir TL Lirası yatırıma karşılık gelen gelirdir. Bir portföyün getirisi, bir önceki döneme göre portföy değerindeki artış oranı ile ölçülmektedir (Karan, 2011: 667-668);

Portföy getirisi $=\left(\right.$ Portföy değeri $_{t}-$ Portföy değeri $\left._{t-1}\right) /$ Portföy değeri $t_{t-1}$

Güncel fon bilgileri, Kamu Aydınlatma Platformu (KAP) ile elde edilmiş ve fonların günlük pay değeri verilerine, Sermaye Piyasası Kurulu (SPK) günlük bülten istatistiklerinden erişilmiştir. SPK menkul kıymet yatırım fonu verilerine 12.11.2002 tarihinden itibaren erişilebilmektedir. Ancak, bir fonun (Ziraat Portföy BiST 30 Endeksi, TZE) 2005 yılında halka arz edilmesinden dolayı eşit sayıda veri ile analiz yapabilmek için çalışma dönemi 04.03.2005 ve 31.12.2015 olarak 2728 gün (yaklaşık 11 yıl) şeklinde belirlenmiştir. Çalışmaya dahil edilen 7 yatırım fonunun ünvanı, kodu, halka arz tarihi ve analize dahil edilen verisi Tablo 1'de verilmiştir. 
Tablo 1. Analize Dahil Edilen Fon Bilgileri

\begin{tabular}{|lllll|}
\hline & Fon Adı* & Fon Kodu & Halka Arz Tarihi & SPK Veri Tarihi \\
\hline 1 & Vakıf Portföy Bist 30 Endeksi HSF & VEF & 16.03 .1999 & 03.01 .2003 \\
2 & Hsbc Portföy Bist 30 Endeksi HSF & HBU & 18.06 .1999 & 12.11 .2002 \\
3 & iş̧ Portföy Bist 30 Endeksi HSF & TIE & 19.04 .2000 & 12.11 .2002 \\
4 & Garanti Portföy Bist 30 Endeksi HSF & GAE & 15.09 .2000 & 12.11 .2002 \\
5 & Ak Portföy Bist 30 Endeksi HSF & AKU & 12.03 .2001 & 12.11 .2002 \\
6 & Yapı Kredi Portföy Bist 30 Endeksi HSF & YEF & 21.06 .2001 & 12.11 .2002 \\
7 & Ziraat Portföy Bist 30 Endeksi HSF & TZE & 28.02 .2005 & 03.03 .2005 \\
\hline
\end{tabular}

Not. HSF kısaltması hisse senedi fonunu ifade etmektedir.

Tablo 1'de yer alan endeks fonlar, hisse senedi yoğun fon kategorisine girmektedir. Bizim Portföy Katılım 30 Endeksi Hisse Senedi Fonu, katılım endeksine dayalı borsa yatırım fonu olduğu için araştırma kapsamı dışında tutulmuştur.

Portföyünün en az \%80'i devamlı olarak, baz alınan ve SPK tarafindan uygun görülen bir endeksin değeri ile fonun birim pay değeri arasındaki korelasyon katsayısı en az $\% 90$ olacak şekilde, endeks kapsamındaki menkul kıymetlerin tümünden ya da örnekleme yoluyla seçilen bir kısmından oluşan fonlar "endeks fon" olarak adlandırılır (Yatıım fonlarına ilişkin esaslar tebliği, Seri: VII, No: 10, s. 355).

Endeks fonlar, fon toplam değerinin en az \%80'i devamlı olarak Borsa i̇stanbul A.Ş.(BíAŞ) de işlem gören ihraç̧̧ı paylarından oluştuğu için "Hisse Senedi Yoğun Fon" olarak kabul edilir (Yatırım fonlarına ilişkin esaslar tebliği, III-52. 1, s.3)

Ünvanında "Endeks" ibaresi yer alan fonlarda yönetici fonu, fonun getirisi baz alınan endeksin getirisinden önemli ölçüde sapmayacak şekilde yönetmekle yükümlüdür. Son üç aylık dönemde, baz alınan endeksin değeri ile fonun birim pay değeri arasındaki korelasyon katsayısının \%90'ın altına düşmesi halinde SPK, söz konusu fonun tasfiyesini veya türünün değiştirilmesini isteyebilir (Yatırım fonlarına ilişkin esaslar tebliği, III-52.1, s.10, Yatıım fonlarına ilişkin esaslar tebliği, Seri: VII, No: 10, s. 377).

Tablo 2. Analize Dahil Edilen Fonların 5 yıllık Performansı

\begin{tabular}{|cccccccc|}
\hline YII/Fon & VEF & HBU & TIE & GAE & AKU & YEF & TZE \\
\hline 2011 & -2.02 & -2.83 & -1.45 & -2.00 & -2.06 & -2.25 & -3.17 \\
2012 & 0.22 & 0.97 & -0.04 & 0.92 & 3.94 & 5.15 & -0.15 \\
2013 & -0.12 & -1.21 & 0.21 & -0.12 & 1.16 & -0.69 & 0.88 \\
2014 & -0.11 & -0.16 & 0.39 & -0.35 & 1.15 & 1.42 & 1.30 \\
2015 & 0.37 & 0.72 & 0.59 & 0.73 & -0.23 & 0.39 & 0.07 \\
\hline
\end{tabular}

Tablo 2'de yer alan getiriler, KAP'da yayınlanan performans sunum raporlarından elde edilen nispi getirileridir. İlgili dönem sonunda portföyün gerçekleşen getiri tutarı ile karşılaştırma ölçütünün getiri oranı aradaki fark, nispi getiri tutarı olarak ifade edilmektedir. 6 aylık dönemler halinde raporlanan fon performans sunumlarında geçmiş yıllar verileri yıllık olarak temin edilebilmiştir. Araştırma kapsamında incelenen 7 fonun son 5 yıllık dönemde nispi getirisinin negatif olduğu dönemler, pozitif olduğu dönemlere eşittir. Ayrıca, bazı dönemlerde fon getirileri arasındaki farklar belirginleşmiştir. Bir başka ifade ile aynı dönem için bir fon karşılaştırma ölçütünden düşük getiri elde ederken diğeri yüksek getiri elde etmiştir. Bu durum, endeks fonlar arasında yönetim etkinliği farkı olduğunun göstergesidir.

\subsubsection{Karşılaştırma Ölçütü}

Bu çalışmada BiST 30 endeks getirisi karşılaştırma ölçütü (gösterge portföy veya benchmark olarak da ifade edilmektedir) olarak kullanılmıştır. BiST 30 endeksinin günlük getirileri de yatırım fonu getirilerinin hesaplandığı 4. formül ile 2. seans kapanış fiyatları dikkate alınarak hesaplanmışttr. Endeks verileri, datastream veri tabanı ve investing.com internet sitesinden temin edilmiştir. 


\subsubsection{Risksiz Faiz Oranı Getirisi}

Finansal çalışmalarda risksiz faizi oranı olarak genellikle üç aylık hazine bonosu faizleri kullanılmaktadır. Ancak son yıllarda üç aylık bono ihraç edilmediğinden dolayı araştırmacılar, risksiz faiz oranının temsil edecek alternatiflere yönelmektedir. Bu alternatiflerden biri KYD- devlet iç borçlanma senetleri (DiBS) endeksi, diğeri ise KYD-O/N Repo endeksidir (Yolsal, 2012: 352-353). Arslan (2005) ve Özek (2014) çalışmalarında, risksiz faiz oranının temsilcisi olarak DiBS getirilerini kullanmıştır. Apak ve Taşşıyan (2009), 90 günlük hazine bonosu faiz oranına göre, Samırkaş ve Düzakın (2012), yılık hazine bonosu faiz tutarına göre riski düzeltmiştir. Karatepe ve Gökgöz (2007) ve Alptekin ve Şıklar (2009), 30 günlük DiBS performans endeksini, Gökgöz (2007), 90 günlük DiBS performans endeksini risksiz faiz oranı göstergesi olarak kullanmıştır.

Bu çalışmada, risksiz faiz oranının temsilcisi olarak T.C. Merkez Bankası elektronik veri dağıtım sisteminden elde edilen DiBS verileri kullanılmıştır. İhalelerde oluşan basit ve bileşik faiz oranının ortalaması dikkate alınarak her bir ay içinde yapılan tüm ihalelerin faiz oranlarının ortalaması hesaplanmıştır. Fonların getirilerinin günlük basit getiriler olması nedeniyle; DiBS aylık ortalama faiz oranı 30'a bölünerek günlük basit getirileri hesaplanmıştir.

Günlük DiBS faiz oranları hesaplanırken yabancı para faiz oranları, reel faiz oranı ve dönemsel faiz oranı dışındaki faiz oranları dikkate alınmıştır. Son yıllarda DiBS ihalelerinde vadelerin uzadığı ve hatta bazı aylar 1 yılın altında bono ihracı bulunmadığı görülmüştür. Ancak, faizler incelendiğinde kısa ve uzun vadeli senetlerin oranları arasında önemli bir fark olmadığı izlenmiş ve bu sebeple genel olarak ilgili ayda gerçekleşen tüm ihalelerin faiz oranı ortalaması alınmıştır. 13 yıllık (157 ay) analiz döneminde sadece 2012 yılında 5., 6. ve 7. aylarda ihale yapılmamış olup ilgili aylarda da bir önceki ay (2012-04) ve bir sonraki ay (2012-08) ortalaması alınmıştır.

\subsection{Analiz Bulguları}

Analize dahil edilen fonlar ve pazarın getiri oranları ve standart sapmalarının yer aldığı Tablo 3'de görüldügü gibi endeks fonlarının getiri ortalaması ve standart sapma ortalaması, pazarın getiri oranı ve standart sapmasından düşüktür. Ortalama fon getirisi ve standart sapması ile hesaplanan değişkenlik katsayısı $0.0265(0.045 / 1.694=0.0265)$ iken pazar portföyünün değişkenlik katsayısı $0.0274(0.051 / 1.859=0.0274)$ olarak hesaplanmaktadır. BIST 30 endeks fonlarının bir birim riske karşı elde ettiği getiri, BiST 30 endeksinin getirisine göre daha düşüktür.

Tablo 3. Fonların Tanımlayıcı İstatistikleri

\begin{tabular}{|cccccc|}
\hline & Fon Kodu & Ri Ort. & Rm Ort. & Ri St.Sap. & Rm St.Sap. \\
\hline 1 & VEF & 0.046 & 0.051 & 1.683 & 1.859 \\
2 & HBU & 0.042 & 0.051 & 1.691 & 1.859 \\
3 & TIE & 0.049 & 0.051 & 1.689 & 1.859 \\
4 & GAE & 0.040 & 0.051 & 1.688 & 1.859 \\
5 & AKU & 0.047 & 0.051 & 1.691 & 1.859 \\
6 & YEF & 0.049 & 0.051 & 1.740 & 1.859 \\
7 & TZE & 0.041 & 0.051 & 1.676 & 1.859 \\
\hline Ortalama & & 0.045 & 0.051 & 1.694 & 1.859 \\
\hline
\end{tabular}

Getiri bazlı değişkenleri durağanlık testine başvurmadan analiz eden çalışmalar olsa da bu çalışmada, zaman serilerinin durağanlığı test edilmiştir. Analiz serilerinin durağan olup olmadığını saptamak için uygulanan Augmented Dickey-Fuller (1979) ve Phillips-Perron (1988) birim kök sınama sonuçları Tablo 4'de sunulmuştur. Testlerinin boş hipotezi, birim kökün varlığını bir başka ifadeyle serinin durağan olmadığını ifade etmektedir. Bu sonuçlara göre analiz verileri birim kök içermemektedir. 
BIST 30 Endeks Fonlarının Seçme ve Zamanlama Yeteneği

Tablo 4. ADF ve PP Birim Kök Sınama Sonuçları

\begin{tabular}{|c|c|c|c|c|c|}
\hline \multirow{3}{*}{ Fon Kodu } & \multirow{3}{*}{ Değişken } & \multicolumn{2}{|c|}{ Augmented Dickey-Fuller } & \multicolumn{2}{|c|}{ Philips-Perron } \\
\hline & & \multicolumn{2}{|c|}{ Düzey } & \multicolumn{2}{|c|}{ Düzey } \\
\hline & & Sabit & Sabit ve Trend & Sabit & Sabit ve Trend \\
\hline \multirow{3}{*}{ VEF } & $\mathrm{R}_{\mathrm{it}}-\mathrm{R}_{\mathrm{ft}}$ & -12.288 & -12.518 & -50.036 & -50.190 \\
\hline & $R_{m t}-R_{f t}$ & -12.530 & -50.888 & -50.835 & -50.929 \\
\hline & $\left(R_{m t}-R_{f t}\right)^{2}$ & -5.970 & -6.146 & -62.920 & -62.342 \\
\hline \multirow{3}{*}{$\mathrm{HBU}$} & $R_{i t}-R_{f t}$ & -12.182 & -12.422 & -50.497 & -50.971 \\
\hline & $R_{m t}-R_{f t}$ & -12.530 & -50.888 & -50.835 & -50.929 \\
\hline & $\left(R_{m t}-R_{f t}\right)^{2}$ & -5.970 & -6.146 & -62.920 & -62.342 \\
\hline \multirow{3}{*}{ TIE } & $\mathrm{R}_{\mathrm{it}}-\mathrm{R}_{\mathrm{ft}}$ & -50.779 & -50.924 & -50.812 & -50.962 \\
\hline & $R_{m t}-R_{f t}$ & -12.530 & -50.888 & -50.835 & -50.929 \\
\hline & $\left(R_{m t}-R_{f t}\right)^{2}$ & -5.970 & -6.146 & -62.920 & -62.342 \\
\hline \multirow{3}{*}{ GAE } & $\mathrm{R}_{\mathrm{it}}-\mathrm{R}_{\mathrm{ft}}$ & -12.260 & -50.261 & -50.148 & -50.312 \\
\hline & $R_{m t}-R_{f t}$ & -12.530 & -50.888 & -50.835 & -50.929 \\
\hline & $\left(R_{m t}-R_{f t}\right)^{2}$ & -5.970 & -6.146 & -62.920 & -62.342 \\
\hline \multirow{3}{*}{ AKU } & $\mathrm{R}_{\mathrm{it}}-\mathrm{R}_{\mathrm{ft}}$ & -12.317 & -50.867 & -50.755 & -50.911 \\
\hline & $R_{m t}-R_{f t}$ & -12.531 & -50.886 & -50.833 & -50.927 \\
\hline & $\left(\mathrm{R}_{\mathrm{mt}}-\mathrm{R}_{\mathrm{ft}}\right)^{2}$ & -5.970 & -6.146 & -62.920 & -62.342 \\
\hline \multirow{3}{*}{ YEF } & $R_{i t}-R_{f t}$ & -52.137 & -52.286 & -52.154 & -52.303 \\
\hline & $R_{m t}-R_{f t}$ & -12.531 & -50.886 & -50.833 & -50.927 \\
\hline & $\left(R_{m t}-R_{f t}\right)^{2}$ & -5.970 & -6.146 & -62.920 & -62.342 \\
\hline \multirow{3}{*}{ TZE } & $\mathrm{R}_{\mathrm{it}}-\mathrm{R}_{\mathrm{ft}}$ & -12.270 & -12.536 & -50.244 & -50.429 \\
\hline & $R_{m t^{-}} R_{f t}$ & -12.530 & -50.888 & -50.835 & -50.929 \\
\hline & $\left(R_{m t}-R_{f t}\right)^{2}$ & -5.970 & -6.146 & -62.920 & -62.342 \\
\hline
\end{tabular}

Not: Sabitli model için kritik değerler; -3.433 (\%1), -2.862 (\%5) ve -2.567 (\%10) ;

Sabit ve trendli model için kritik değerler $-3.961(\% 1),-3.411$ (\%5) ve $-3.128(\% 10)^{\prime}$ dir.

Augmented Dickey-Fuller testinde uygun gecikme uzunluğu Akaike bilgi kriterine göre belirlenmiştir. Phillips-Peron testinde "Barlett kernel” yöntemi ve bant genişliği (bandwith) "Newey West bandwith" yöntemi kullanılmıştır.

Tablo 5. Jensen-Alfası Modeli Değişkenlerinin Parametre Tahminleri

\begin{tabular}{|c|c|c|cc|cc|cc|}
\hline $\begin{array}{c}\text { Fon } \\
\text { Kodu }\end{array}$ & Değişken & Katsayı & $\begin{array}{c}\text { EKK } \\
\text { t-ist. }\end{array}$ & $\begin{array}{c}\mathrm{p} \\
\text { değeri }\end{array}$ & $\begin{array}{c}\mathrm{NW}(0) \\
\text { t.ist }\end{array}$ & $\begin{array}{c}\mathrm{p} \\
\text { değeri }\end{array}$ & $\begin{array}{c}\mathrm{NW}(\mathrm{AIC}) \\
\text { t.ist }\end{array}$ & $\begin{array}{c}\mathrm{p} \\
\text { değeri }\end{array}$ \\
\hline \multirow{2}{*}{$\mathrm{VEF}$} & $\mathrm{a}_{\mathrm{i}}$ & -0.3555 & -10.775 & 0.000 & -10.781 & 0.000 & -10.567 & 0.000 \\
& $\mathrm{R}_{\mathrm{mt}}-\mathrm{R}_{\mathrm{ft}}$ & 0.0284 & 1.639 & 0.101 & 1.467 & 0.143 & 1.470 & 0.142 \\
\hline \multirow{2}{*}{$\mathrm{HBU}$} & $\mathrm{a}_{\mathrm{i}}$ & -0.3604 & -10.869 & 0.000 & -10.932 & 0.000 & -10.734 & 0.000 \\
& $\mathrm{R}_{\mathrm{mt}}-\mathrm{R}_{\mathrm{ft}}$ & 0.0262 & 1.502 & 0.133 & 1.361 & 0.174 & 1.350 & 0.177 \\
\hline \multirow{2}{*}{ TIE } & $\mathrm{a}_{\mathrm{i}}$ & -0.3532 & -10.6634 & 0.0000 & -10.7470 & 0.0000 & -10.5841 & 0.0000 \\
& $\mathrm{R}_{\mathrm{mt}}-\mathrm{R}_{\mathrm{ft}}$ & 0.0260 & 1.4921 & 0.1358 & 1.3772 & 0.1686 & 1.3888 & 0.1650 \\
\hline \multirow{2}{*}{$\mathrm{GAE}$} & $\mathrm{a}_{\mathrm{i}}$ & -0.3620 & -10.9320 & 0.0000 & -10.8410 & 0.0000 & -10.5349 & 0.0000 \\
& $\mathrm{R}_{\mathrm{mt}}-\mathrm{R}_{\mathrm{ft}}$ & 0.0264 & 1.5169 & 0.1294 & 1.3453 & 0.1786 & 1.3248 & 0.1853 \\
\hline \multirow{2}{*}{ AKU } & $\mathrm{a}_{\mathrm{i}}$ & -0.3544 & -10.6872 & 0.0000 & -10.7420 & 0.0000 & -10.5148 & 0.0000 \\
& $\mathrm{R}_{\mathrm{mt}}-\mathrm{R}_{\mathrm{ft}}$ & 0.0266 & 1.5267 & 0.1269 & 1.3695 & 0.1710 & 1.3694 & 0.1710 \\
\hline \multirow{2}{*}{$\mathrm{YEF}$} & $\mathrm{a}_{\mathrm{i}}$ & -0.3529 & -10.3436 & 0.0000 & -10.6526 & 0.0000 & -10.4743 & 0.0000 \\
& $\mathrm{R}_{\mathrm{mt}}-\mathrm{R}_{\mathrm{ft}}$ & 0.0261 & 1.4546 & 0.1459 & 1.3268 & 0.1847 & 1.3081 & 0.1910 \\
\hline \multirow{2}{*}{ TZE } & $\mathrm{a}_{\mathrm{i}}$ & -0.3613 & -10.9927 & 0.0000 & -10.9720 & 0.0000 & -10.7287 & 0.0000 \\
& $\mathrm{R}_{\mathrm{mt}}-\mathrm{R}_{\mathrm{ft}}$ & 0.0263 & 1.5183 & 0.1291 & 1.3477 & 0.1779 & 1.3278 & 0.1844 \\
\hline
\end{tabular}

Not: EKK, En Küçük Kareler; NW, Newey-West dirençli standart hatalarla tahmin edilen modeli ifade etmektedir. NW (0), sıfır gecikme uzunluğuna göre hesaplanan Newey-West modelini gösterirken, NW (AIC), Akaike bilgi kriterine göre belirlenen gecikme uzunluğunu göstermektedir. 
Zaman serisi analizlerinde Standart En Küçük Kareler (EKK) ve Newey-West (NW) standart hatalı parametre tahminleri yapılmıştır. Günlük zaman serisi verilerinin analizinde potansiyel yatay kesit bağımlılığı ve değişen varyansı düzelten Newey-West t-istatistiği uygulanmıştır. Newey-West düzeltilmiş t-istatistiği Stotz (2007: 65) ve Christensen (2013: 819) çalışmalarında kullanılmıştır. En Küçük Kareler ise Dhar ve Mandal (2014: 303) çalışmasında kullanılmıştır.

Her bir fon için ayrı tahmin edilen Jensen-Alfası, Treynor-Mazuy ve Henriksson-Merton modellerinde, EKK ve NW standart hatalı parametre tahminleri yapılmıştır. Sıfir gecikme uzunluğu ve Akaike (AIC) bilgi kriteri ile belirlenen gecikme uzunluğuna göre iki NW standart hatası hesaplanmıştır. 2728 gözlem sayılı fonların regresyon analizleri parametre tahmin sonuçları Tablo 5, Tablo 6, Tablo 7 ve Tablo 8'de verilmiştir. il|gili tablolar zaman serisi regresyon analizlerinin kesişim (sabit) değerlerini $\left(a_{i}\right)$, eğim katsayılarını $\left(b_{i}\right)$ ve önem düzeylerini ( $t$-istatistiği ve $p$ değerleri ile) vermektedir.

Tablo 5'de yer alan sonuçlara göre Türk BiST 30 endeks fonlarının tamamında \%1 düzeyinde anlamlı negatif alfa tahmin edilmiştir. Jensen regresyon sabitinin davranışına göre hiçbir fon seçicilik yeteneğine sahip değildir.

Tablo 6. Treynor-Mazuy Modeli Değişkenlerinin Parametre Tahminleri

\begin{tabular}{|c|c|c|c|c|c|c|c|c|}
\hline Fon Kodu & Değişken & Katsayı & EKK t-ist. & p değeri & $\mathrm{NW}(0)$ t. ist & p değeri & $\begin{array}{c}\text { NW (AIC) } \\
\text { t.ist }\end{array}$ & $p$ değeri \\
\hline \multirow{3}{*}{ VEF } & $a_{i}$ & -0.2795 & -7.8737 & 0.0000 & -8.2142 & 0.0000 & -7.5333 & 0.0000 \\
\hline & $R_{m t}-R_{f t}$ & 0.0085 & 0.4832 & 0.6290 & 0.3683 & 0.7127 & 0.3540 & 0.7234 \\
\hline & $\left(R_{m t}-R_{f t}\right)^{2}$ & -0.0230 & -5.6100 & 0.0000 & -3.8445 & 0.0001 & -3.9368 & 0.0001 \\
\hline \multirow{3}{*}{$\mathrm{HBU}$} & $a_{i}$ & -0.2843 & -7.9696 & 0.0000 & -8.3105 & 0.0000 & -7.5847 & 0.0000 \\
\hline & $R_{m t^{-}} R_{f t}$ & 0.0062 & 0.3526 & 0.7244 & 0.2684 & 0.7884 & 0.2576 & 0.7967 \\
\hline & $\left(R_{m t}-R_{f t}\right)^{2}$ & -0.0230 & -5.5856 & 0.0000 & -3.7986 & 0.0001 & -3.9592 & 0.0001 \\
\hline \multirow{3}{*}{ TIE } & $a_{i}$ & -0.2774 & -7.7830 & 0.0000 & -8.1370 & 0.0000 & -7.5023 & 0.0000 \\
\hline & $R_{m t^{-}} R_{f t}$ & 0.0061 & 0.3455 & 0.7298 & 0.2706 & 0.7867 & 0.2613 & 0.7939 \\
\hline & $\left(R_{m t}-R_{f t}\right)^{2}$ & -0.0230 & -5.5732 & 0.0000 & -3.9204 & 0.0001 & -4.0450 & 0.0001 \\
\hline \multirow{3}{*}{ GAE } & $a_{i}$ & -0.2850 & -7.9992 & 0.0000 & -8.2448 & 0.0000 & -7.5401 & 0.0000 \\
\hline & $R_{\mathrm{mt}}-\mathrm{R}_{\mathrm{ft}}$ & 0.0062 & 0.3515 & 0.7253 & 0.2651 & 0.7909 & 0.2526 & 0.8006 \\
\hline & $\left(R_{m t}-R_{f t}\right)^{2}$ & -0.0233 & -5.6661 & 0.0000 & -3.8035 & 0.0001 & -3.9269 & 0.0001 \\
\hline \multirow{3}{*}{$A K U$} & $a_{i}$ & -0.2776 & -7.7797 & 0.0000 & -8.1062 & 0.0000 & -7.4289 & 0.0000 \\
\hline & $R_{m t}-R_{f t}$ & 0.0065 & 0.3654 & 0.7149 & 0.2756 & 0.7828 & 0.2660 & 0.7902 \\
\hline & $\left(R_{m t}-R_{f t}\right)^{2}$ & -0.0233 & -5.6438 & 0.0000 & -3.7986 & 0.0001 & -3.8737 & 0.0001 \\
\hline \multirow{3}{*}{ YEF } & $a_{i}$ & -0.2762 & -7.5213 & 0.0000 & -8.0349 & 0.0000 & -7.3889 & 0.0000 \\
\hline & $R_{m t}-R_{f t}$ & 0.0060 & 0.3277 & 0.7431 & 0.2552 & 0.7986 & 0.2423 & 0.8086 \\
\hline & $\left(R_{m t}-R_{f t}\right)^{2}$ & -0.0232 & -5.4756 & 0.0000 & -3.8240 & 0.0001 & -3.9417 & 0.0001 \\
\hline \multirow{3}{*}{ TZE } & $a_{i}$ & -0.2856 & -8.0748 & 0.0000 & -8.3711 & 0.0000 & -7.6228 & 0.0000 \\
\hline & $\mathrm{R}_{\mathrm{mt}}-\mathrm{R}_{\mathrm{ft}}$ & 0.0064 & 0.3634 & 0.7163 & 0.2735 & 0.7845 & 0.2588 & 0.7958 \\
\hline & $\left(R_{m t}-R_{f t}\right)^{2}$ & -0.0229 & -5.6128 & 0.0000 & -3.7929 & 0.0002 & -3.8375 & 0.0001 \\
\hline
\end{tabular}

Not: EKK, En Küçük Kareler; NW, Newey -West dirençli standart hatalarla tahmin edilen modeli ifade etmektedir. NW (0), sıfır gecikme uzunluğuna göre hesaplanan Newey -West modelini gösterirken, NW (AIC), Akaike bilgi kriterine göre belirlenen gecikme uzunluğunu göstermektedir.

Tablo 6'de yer alan Treynor-Mazuy kuadratik regresyon sonuçlarının özet gösteriminde, fon yöneticilerinin zamanlama yeteneğini ölçen negatif kuadratik terim katsayısı (c katsayısı), tüm fonlar için \%1 önem seviyesinde istatistiki olarak anlamlı negatif değere sahiptir. Bu sonuç, fon yöneticilerinin piyasa zamanlaması yeteneğine sahip olmadığını ortaya koymaktadır. 
BísT 30 Endeks Fonlarının Seçme ve Zamanlama Yeteneği

Tablo 7. Henriksson-Merton Modeli Değişkenlerinin Parametre Tahminleri

\begin{tabular}{|c|c|c|c|c|c|c|c|c|}
\hline $\begin{array}{l}\text { Fon } \\
\text { Kodu }\end{array}$ & Değişken & Katsayı & EKK t-ist. & p değeri & $N W(0)$ t. ist & p değeri & $\begin{array}{c}\text { NW (AIC) } \\
\text { t.ist }\end{array}$ & $p$ değeri \\
\hline \multirow{3}{*}{ VEF } & $a_{i}$ & -0.5185 & -8.7200 & 0.0000 & -8.0070 & 0.0000 & -7.3965 & 0.0000 \\
\hline & $R_{m t}-R_{f t}$ & 0.0896 & 3.5281 & 0.0004 & 2.9958 & 0.0028 & 2.7194 & 0.0066 \\
\hline & $\mathrm{D}\left(\mathrm{R}_{\mathrm{mt}}-\mathrm{R}_{\mathrm{ft}}\right)$ & -0.3167 & -3.2926 & 0.0010 & -3.1971 & 0.0014 & -2.9808 & 0.0029 \\
\hline \multirow{3}{*}{$\mathrm{HBU}$} & $a_{i}$ & -0.5158 & -8.6294 & 0.0000 & -7.9374 & 0.0000 & -7.3343 & 0.0000 \\
\hline & $R_{m t}-R_{f t}$ & 0.0845 & 3.3097 & 0.0009 & 2.8398 & 0.0045 & 2.5332 & 0.0114 \\
\hline & $\mathrm{D}\left(\mathrm{R}_{\mathrm{mt}}-\mathrm{R}_{\mathrm{ft}}\right)$ & -0.3020 & -3.1227 & 0.0018 & -3.0318 & 0.0025 & -2.8175 & 0.0049 \\
\hline \multirow{3}{*}{ TIE } & $a_{i}$ & -0.5113 & -8.5647 & 0.0000 & -7.9151 & 0.0000 & -7.1864 & 0.0000 \\
\hline & $R_{m t}-R_{f t}$ & 0.0853 & 3.3461 & 0.0008 & 2.9399 & 0.0033 & 2.7397 & 0.0062 \\
\hline & $\mathrm{D}\left(\mathrm{R}_{\mathrm{mt}}-\mathrm{R}_{\mathrm{ft}}\right)$ & -0.3073 & -3.1816 & 0.0015 & -3.1168 & 0.0018 & -2.8955 & 0.0038 \\
\hline \multirow{3}{*}{ GAE } & $a_{i}$ & -0.5170 & -8.6603 & 0.0000 & -7.8371 & 0.0000 & -7.1303 & 0.0000 \\
\hline & $R_{m t}-R_{f t}$ & 0.0846 & 3.3165 & 0.0009 & 2.7562 & 0.0059 & 2.4420 & 0.0147 \\
\hline & $D\left(R_{m t}-R_{f t}\right)$ & -0.3012 & -3.1180 & 0.0018 & -2.9672 & 0.0030 & -2.7141 & 0.0067 \\
\hline \multirow{3}{*}{ AKU } & $a_{i}$ & -0.5121 & -8.5673 & 0.0000 & -7.8584 & 0.0000 & -7.2375 & 0.0000 \\
\hline & $\mathrm{R}_{\mathrm{mt}}-\mathrm{R}_{\mathrm{ft}}$ & 0.0859 & 3.3624 & 0.0008 & 2.8557 & 0.0043 & 2.5916 & 0.0096 \\
\hline & $D\left(R_{m t}-R_{f t}\right)$ & -0.3067 & -3.1714 & 0.0015 & -3.0600 & 0.0022 & -2.8494 & 0.0044 \\
\hline \multirow{3}{*}{ YEF } & $a_{i}$ & -0.5080 & -8.2589 & 0.0000 & -7.7309 & 0.0000 & -7.0615 & 0.0000 \\
\hline & $R_{m t}-R_{f t}$ & 0.0843 & 3.2083 & 0.0014 & 2.7513 & 0.0060 & 2.4447 & 0.0146 \\
\hline & $\mathrm{D}\left(\mathrm{R}_{\mathrm{mt}}-\mathrm{R}_{\mathrm{ft}}\right)$ & -0.3013 & -3.0282 & 0.0025 & -2.9701 & 0.0030 & -2.7214 & 0.0065 \\
\hline \multirow{3}{*}{ TZE } & $a_{i}$ & -0.5166 & -8.7186 & 0.0000 & -7.9729 & 0.0000 & -7.3077 & 0.0000 \\
\hline & $R_{m t}-R_{f t}$ & 0.0845 & 3.3389 & 0.0009 & 2.8150 & 0.0049 & 2.5149 & 0.0120 \\
\hline & $D\left(R_{m t}-R_{f t}\right)$ & -0.3017 & -3.1473 & 0.0017 & -3.0364 & 0.0024 & -2.8109 & 0.0050 \\
\hline
\end{tabular}

Not: EKK (En Küçük Kareler), NW, Newey -West dirençli standart hatalarla tahmin edilen modeli ifade etmektedir. NW (0), sıfır gecikme uzunluğuna göre hesaplanan Newey -West modelini gösterirken, NW (AIC), Akaike bilgi kriterine göre belirlenen gecikme uzunluğunu göstermektedir.

Fonların, Tablo 7'de yer alan Henriksson-Merton regresyon analizi özet sonuçlarında izlenen kukla değişken katsayıları, Treynor-Mazuy kuadratik regresyon sonuçlarıyla uyumludur. Bu yöntemde de anlamlı negatif " $c$ " katsayıları incelenen fonların zamanlama yeteneği sergileyemediklerini göstermektedir.

Treynor-Mazuy ve Henriksson-Merton modellerinin tahmininde elde edilen alfa değerleri aynı zamanda zamana göre değişen seçicilik yeteneğinin göstergesidir. Bu modellerin anlamlı negatif regresyon sabitleri de Jensen modeli sonucunu desteklemektedir.

Tablo 5, Tablo 6 ve Tablo 7 ile tüm parametre tahminlerinin EKK ve NW standart hataları raporlanmışttr. Tablo 8 ise genel değerlendirmenin daha sade bir tablo üzerinden yapılabilmesi amacıyla ilgili modellerinin sadece zamanlama ve seçicilik yeteneğini ölçen "a" ve "c" katsayıları, NW(0) standart hataları ve önem düzeylerini içermektedir. EKK, NW(0) ve NW(AIC) standart hataları birbirine çok yakın değerler olduğundan NW(0) standart hataları dikkate alınmıştır.

Jensen-Alfası regresyon analizinde tüm endeks fonları, istatistiki olarak anlamlı negatif regresyon sabitine sahiptir. Negatif alfa, yöneticinin pazardan iyi performans gösteren hisse senedini seçme yeteneğinin olmadığını göstermektedir. Bir başka ifade ile aktif fon yönetiminin, düşük fiyatlanmış/yanlış değerlenmiş sektör veya firmaları belirleyerek değer yaratamadığı anlaşılmaktadır. Bu bulgular, Jensen ölçümüne göre fon yöneticilerin seçme yeteneği olmadığı sonucuna varan Alttntaş (2008) ve Korkmaz ve Uygurtürk (2009)'ün bulguları ile uyumludur. Buna rağmen bu bulgu, seçme yeteneğini Treynor - Mazuy regresyon modelinin alfasına göre başarılı değerlendiren Korkmaz ve Uygurtürk (2007), Gökgöz (2007), Karatepe ve Gökgöz (2007) analiz sonuçlarından farklılık göstermektedir. 
A. Sahin

Tablo 8. Seçicilik ve Zamanlama Yeteneği Parametreleri

\begin{tabular}{|c|c|c|c|}
\hline \multirow{3}{*}{ Fon Kodu } & $\mathrm{JA}, \mathrm{NW}(0)$ & $\mathrm{T} / \mathrm{M}, \mathrm{NW}(0)$ & $\mathrm{H} / \mathrm{M}, \mathrm{NW}(0)$ \\
\cline { 2 - 4 } & $\mathrm{ai}$ & $\mathrm{ci}$ & $\mathrm{ci}$ \\
\hline VEF & $-0.3555^{* * *}$ & $-0.0230^{* * *}$ & $-0.3167^{* * *}$ \\
HBU & $-0.3604^{* * *}$ & $-0.0230^{* * *}$ & $-0.3020^{* * *}$ \\
TIE & $-0.3532^{* * *}$ & $-0.0230^{* * *}$ & $-0.3073^{* * *}$ \\
GAE & $-0.3620^{* * *}$ & $-0.0233^{* * *}$ & $-0.3012^{* * *}$ \\
AKU & $-0.3544^{* * *}$ & $-0.0233^{* * *}$ & $-0.3067^{* * *}$ \\
YEF & $-0.3529 * * *$ & $-0.0232^{* * *}$ & $-0.3013^{* * *}$ \\
TZE & $-0.5361^{* * *}$ & $-0.0229^{* * *}$ & $-0,3017^{* * *}$ \\
\hline
\end{tabular}

Not: Sıfır gecikmeli Newey West standart hatalara, NW(0), göre katsayıların anlam düzeyi belirlenmiştir. JA, Jensen-Alfasını; T-M, Treynor-Mazuy, H-M Henriksson-Merton modelini ifade etmektedir.

$* * * p<.01, * * p<.05, * p<.1$ ve $* * *, * *$ ve $*$ sırasıyla $\% 1, \% 5$ ve $\% 10$ anlamlılık düzeyini göstermektedir.

Yöneticilerin değer yaratabileceği diğer opsiyonu, pazar zamanlamasıdır. Zamanlama ile fon yöneticisi, pazar getirisini tahmin ederek pazara karşı maruz kalacağı riski değiştirebilir. Portföy yöneticilerinin zamanlama yeteneklerini test etmek üzere uygulanan Treynor-Mazuy ve Henriksson-Merton modellerinde, tüm fonların tahmin edilen c katsayıları istatistiki açıdan önemli düzeyde negatiftir. Pazar zamanlama faktörü c, negatif ise fon yöneticileri yeterli zamanlama yeteneği göstermez ve pazar koşullarındaki değişiklikleri iyi öngöremedikleri için portföylerini aktif olarak düzeltemezler. Bu sonuçlara göre, 2005-2015 yıllarında incelenen 7 fonun hiçbiri karakteristik doğrusunun eğimine uyum sağlamamış ve zamanlama yeteneği göstermemiştir. BIST 30 endeks yatırım fonu yatırımcıları, genel pazar hareketlerinden gelir elde edememiştir. Bu bulgular, A tipi ve emeklilik yatırım fonlarının zamanlama yeteneğini aynı yöntemler ile ölçen 5 çalışma (Arslan, 2005; Gökgöz, 2007; Korkmaz ve Uygurtürk, 2007; Korkmaz ve Uygurtürk, 2009; Altnntaş, 2008) sonuçları ile uyumludur.

Analiz bulguları hep birlikte değerlendirildiğinde son 11 yılda BiST 30 endeks fonlarının seçicilik ve zamanlama yeteneği göstermede başarılı olmadığı söylenebilmektedir. Elde edilen bulgular, aynı yöntemleri (Jensen Alfa, T/M ve H/M) kullanarak her iki yetenek için de fon yöneticilerini başarısız değerlendiren Altnntaş (2008) ve Korkmaz ve Uygurtürk (2009)'ün çalışma bulguları ile uyumludur. Tan (2015), Güney Afrika pazarı için aynı yöntemlerle aynı sonuca varmıştır.

\section{Sonuç}

Profesyonel yöneticiler tarafindan yönetilen yatırım fonlarının performansı değerlendirilirken aslında fon yöneticilerinin performansı değerlendirilmektedir. Yatırım fonu yöneticilerinin performansının kaynağında bulunan iki temel bileşen, hisse senedi seçimi ve pazar zamanlamasıdır.

Fon yöneticileri, doğru hisse senedini seçerek fonun performansına katkı sağlayabilirler. Seçme kabiliyetine sahip olan yatırım fonu yöneticileri, düşük fiyatlanmış/yanlış değerlenmiş sektör veya firmaları bir başka ifade ile iyi performans gösteren hisse senedini tahmin edebilen yöneticilerdir. Başarılı zamanlama yapan yöneticiler ise yönettikleri fonun riskini, pazar öngörülerine göre düzenleyerek yatırımcısına genel pazar hareketlerinden gelir elde etme imkanı sunarlar.

Aktif yönetilen ve yatırımcısına fon yönetim ücreti yansıtan endeks fonlarının kurulma amacı, baz endeks getirisine paralel getiri sunmaktır. Baz endeks ile yüksek korelasyon halinde faaliyet gösterme koşulu, endeks fon yöneticilerinin seçme ve zamanlama yeteneği sergilemesine sınırlama getirmektedir. Buna karşılık, menkul kıymetlere baz endeks ile aynı oranda yatırım yapma zorunluluğu bulunmaması, payların firma ve sektörlere dağılım oranında bir serbestlik tanımaktadır. Dolayısıyla, minimum baz endeks getirisi kadar getiri elde etmesi beklenen endeks fon yöneticilerinin bu amaçlarına ulaşabilmesi için etkin bir fon yönetimi sergilemesi beklenmektedir. 
Endeks fon yöneticilerin de seçme ve zamanlama yeteneği sergilemesinin kaçınılmaz olduğu düşünülerek bu çalışmada 7 adet BIST 30 endeks yatırım fonunda seçme ve zamanlama yeteneğinin varlığı 2005 ve 2015 döneminin günlük verilerine Jensen-Alfa, Treynor-Mazuy ve Henriksson-Merton modelleri uygulanarak araştırılmıştır.

Öncelikle, araştırmaya dahil edilen fonların geçmiş 5 yıllık nispi getirisi incelendiğinde, negatif getirili dönem sayısının yüksek olduğu görülmüştür. Pasif yönetilen baz endekse yatırım yapmak yerine fon yönetim ücretine katlanarak aktif yönetilen endeks fona yatırım yapan yatrımcılar, düşük nispi getiriye maruz kalmıştır. Yıllık nispi getiriler ile varılan bu sonuç, günlük getirilerin analiz edilmesi ile de teyit edilmiştir.

Jensen modeli tahmininde bütün fonlar istatistiki olarak anlamlı negatif alfaya sahiptir. Bu bulgu, bütün fon yöneticilerinin menkul kıymet fiyatlarını yeterince iyi tahmin edemediğini ve seçicilik yeteneğine sahip olmadığını göstermektedir. ikinci olarak, yöneticilerin analiz dönemi boyunca zamanlama kabiliyetlerini ölçmek üzere uygulanan Treynor-Mazuy ve Henriksson-Merton modellerinden elde edilen istatistiki olarak anlamlı negatif " $c$ " katsayıları, bu fon yöneticilerinin piyasa zamanlaması stratejilerinde de başarı gösteremedikleri sonucunu ortaya koymaktadır. Fon yöneticileri, pazar yükselmeden (düşmeden) önce alım (satım) yapamamış ve pazar zamanlama çabalarında yetersiz kalmıştır. Bu sonuçlara göre BiST 30 endeksi fon yöneticileri, yatırımcılarına daha iyi seçim ve zamanlama ile ek getiri sağlamada başarılı olamamıştır.

BIST 30 endeks fonlarının gerek kendi performans raporlarında sundukları yıllık nispi getiriler gerekse bu çalışmanın günlük verileri ile yapılan analizler ile ortaya çıkan sonuçlar, fonların yatırımcısına baz endeksten üstün getiri sunamadıklarını göstermektedir. Bu durumun bu çalışmada üzerinde durulan nedeni, yöneticilerinin yönetim başarısızlığı olmuştur. Ayrıca, bu çalışmada analiz edilmeyen fon yönetim giderleri de net fon getirisini düşüren diğer bir diğer faktördür.

SPK'nın endeks yatırım fonlarına ilişkin düzenlemesi, fon yöneticilerine baz endeksten belli seviyede düşük getiri elde ederek fonu yönetebilme imkanı sunmaktadır. Bir başka ifadeyle endeks fon, sürekli olarak baz endeksin belli bir seviye altında getiri sunarak \%90 korelasyon koşulunu sağlayabilmektedir. Bu noktadan hareketle, endeks fonlara ilişkin düzenlemelere yöneticilerin seçme ve zamanlama yeteneği sergileme istekliliğini artrabilecek ve fon yönetim giderlerine sınırlama getirebilecek bir getiri koşulu eklenebilir. Bu getiri koşulu, belirli dönemler için karşılaştırma ölçütünden düşük getiri elde etme oranına veya düşük getiri elde etme dönem sayısına sınırlama şeklinde olabilir.

Bundan sonra yapılacak çalışmalarda, diğer endeks fonlarının performansı, yatırım fonları performansının belirleyicileri ve fon yönetim ücreti ile performans ilişkisi araştırılabilir.

\section{Kaynaklar}

Alper, D., \& Ertan, Y. (2008). Yatırım fonu seçim kararlarında çerçeveleme etkisi. Muhasebe ve Finansman Dergisi, 174184.

Alptekin, N., \& Şıklar, E. (2009). Türk hisse senedi emeklilik yatırım fonlarııı çok kriterli performans değerlendirmesi: Topsis metodu. Dumlupınar Üniversitesi Sosyal Bilimler Dergisi, 25, 185-196.

Altıntaş, K.M. (2008). Türk özel emeklilik fonlarının risk odaklı yönetim performansı: 2004-2006 dönemine ilişkin bir analiz. Anadolu Üniversitesi Sosyal Bilimler Dergisi, 8(1), 85-110.

Apak, S., \& Taş̧̧ıan, K. H. (2009). Morningstar yıldız derecelendirme sistemi ile Türk emeklilik yatırım fonlarının performanslarının değerlendirilmesi. Journal of Accounting \& Finance. 44, 80-90.

Arslan, M. (2005). A tipi yatıım fonlarında yöneticilerin zamanlama kabiliyeti ve performans ilişkisi analizi: 2002-2005 dönemi bir uygulama. Gazi Üniversitesi Ticaret ve Turizm Eğitim Fakültesi Dergisi, 2,1-23.

Bauer, R. , Derwall, J., \& Otten, R. (2007). The ethical mutual fund performance debate: New evidence from Canada. Journal of Business Ethics, 70, 111-124.

Berk, J.B., \& Green, R.C. (2004). Mutual fund flows and performance in rational markets. Journal of Political Economy, $112(6), 1269-1295$. 
Bialkowskia, J., \& Ottenb, R. (2011). Emerging market mutual fund performance: Evidence for Poland. North American Journal of Economics and Finance, 22(2), 118-130.

Blake, C.R., Elton, E.J., \& Gruber, M.J. (1993). The performance of bond mutual funds. Journal of Business, 66(3), 371403.

Bodie, Z. , Kane, A. \& Marcus, A. (2001). Investments (5th ed.). McGraw-Hill/ Irwin. ISBN: 0-90-32002-1.

Cai, J. , Chan, K.C. \& Yamada, T. (1997). The performance of Japanese mutual funds. Review of Financial Studies, 10 (2), 237-273.

Canbaş, S. \& Doğukanlı H. (2012), Finansal kurumlar ve sermaye Pazarı analizleri (5. bs.). Adana: Karahan Kitabevi. ISBN:978-975-6447-56-7.

Carlson, R.S. (1970). Aggregated performance of mutual funds, 1948-1967. Journal of Financial and Quantitative Analysis, 5(1), 1-32.

Christensen, M. (2013). Danish mutual fund performance. Applied Economics Letters, 20, 818-820.

Dahlquist, M. , Engstrom, S., \& Soderlind, P. (2000). Performance and characteristics of Swedish mutual funds. Journal of Financial and Quantitative Analysis, 35(3), 409-423.

Daniel, K. , Grinblatt,M., Titman, S., \& Wermers, R. (1997). Measuring mutual fund performance with characteristicbased benchmarks. Journal of Finance, 52(3), 1035-1058.

Detzler, M.L. (1999). The performance of global bond mutual funds. Journal of Banking \& Finance, 23, 1195-1217.

Dhar, J., \& Mandal, K. (2014). Market timing abilities of Indian mutual fund managers: An empirical analysis. Decision, 41(3), 299-311.

Elton, E.J. , Gruber, M.J., \& Blake, C.R. (1996). Survivorship bias and mutual fund performance. Review of Financial Studies, 9 (4), 1097-1120.

Elton, E. J. , Gruber, M. J. , Brown, S. J., \& Goetzmann, W.N. (2011). Modern portfolio theory and investment analysis. Asia: John Wiley \& Sons Inc. (8th international ed.). ISBN: 978-0-470-50584-7.

Farrel, J. L. (1997). Portfolio management theory and application. Singapore: McGraw-Hill (2nd international ed.). ISBN:0-07-114244-4.

Gallo, J.G. , Lockwood, L.J,. \& Swanson, P.E. (1997). The performance of international bond funds. International Review of Economics and Finance, 6(1), 17-35.

Grinblatt, M., \& Titman, S. (1989). Los Angeles mutual fund performance: An analysis of quarterly portfolio holdings. Journal of Business, 62(3), 393-416.

Grinblatt, M., \& Titman, S. (1994). A study of monthly mutual fund returns and performance evaluation techniques. Journal of Financial and Quantitative Analysis, 29(3), 419-444.

Gökgöz, F. (2007). Bireysel emeklilik fonlarının performans değerlendirmesi. Hacettepe Üniversitesi iktisadi ve idari Bilimler Fakültesi Dergisi, 25(1), 259-291

Henriksson, R. D., \& Merton, R. C. (1981). On market timing and investment performance. II. Statistical procedures for evaluating forecasting skills. The Journal of Business, 54(4), 513-533.

Horowitz, I. (1966). The "reward-to-variability" ratio and mutual fund performance. Journal of Business, 39(4), 485-488.

Ippolito, R.A. (1989). Efficiency with costly information: A study of mutual fund performance, 1965-1984. Quarterly Journal of Economics, 104 (1), 1-23.

Jensen, M.C. (1968). The performance oof mutual funds in the period 1945-1964. Journal of Finance, 23 (2), $389-416$.

Karan, M. B. (2011). Yatırım analizi ve portföy yönetimi (3. bs.). Ankara: Gazi Kitabevi. ISBN: 978-975-7313-99-1.

Karatepe, Y., \& Gökgöz, F. (2007). A-tipi yatırım fonu performansının değerlendirilmesi ve performans devamlılık analizi. Ankara Üniversitesi SBF Dergisi, 62(2), 075-109.

Kim, T. (1978). An assessment of the performance of mutual fund management: 1969-1975. Journal of Financial and Quantitative Analysis, 13(3), 385-406.

Korkmaz, T., \& Uygurtürk, H. (2007). Türkiye'deki emeklilik fonlarının performans ölçümü ve fon yöneticilerinin zamanlama yeteneği. Akdeniz Iktisadi ve Idari Bilimler Fakültesi Dergisi, 7(14), 66-93

Korkmaz, T., \& Uygurtürk, H. (2009). Türkiye'de işlem gören hisse senedi ağırlıklı yatırım fonlarının performans karşılaştırması. Akademik Araştırmalar ve Çalışmalar Dergisi, 1 (1),1-15.

Lehmann, B.N., \& Modest, D. M. (1987). Mutual fund performance evaluation: A comparison of benchmarks and benchmark comparisons. Journal of Finance, 42(2), 233-265. 
McDonald, J.G. (1973). French mutual fund performance: Evaluation of internationally-diversified portfolios. Journal of Finance, 28(5), 1161-1180.

Özek, P. (2014). Yatırım fonu performansının portföy bilgileri ile ilişkili olarak analiz edilmesi,

Celal Bayar Üniversitesi Sosyal Bilimler Enstitüsü Sosyal Bilimler Dergisi, 12(2), 42-55.

Samırkaş, M.C., \& Düzakın, H. (2012). Türkiye'deki A ve B tipi yatırım fonlarının performans analizi. Çukurova Üniversitesi Sosyal Bilimler Enstitüsü Dergisi, 21(3), 391-410.

Sarıtaş, H. (2005). Yatırım fonu karakteristiklerinin getiri üzerindeki etkisi. Muhasebe ve Finansman Dergisi, 169-175.

Sharpe, W.F. (1966). Mutual fund performance. Journal of Business, 39(1), 119-138.

Stotz, O. (2007). Selection, market timing and style timing of equity mutual funds- evidence from Germany. Zeitschrift fur Betriebswirtschaft, 77(1), 51- 73.

Tan, Ö. F. (2015). Mutual fund performance: Evidence from South Africa. Emerging Markets Journal, 5(2), 49-57.

Treynor, J.L. (1965). How to rate management of investment funds. Harward Business Review. 43(1), 131-136.

Treynor, J. L., \& Mazuy, K.K. (1966). Can mutual funds outguess the market? Harvard Business Review, 44(4), $131-136$.

Yatırım fonlarına ilişkin esaslar tebliği, III-52.1 (19/12/1996 tarihli ve 22852 sayılı Resmi Gazete), http://www.spk.gov.tr /apps/MevzuatEski adresinden 17.08.2016 tarihinde edinilmiştir.

Yatırım fonlarına ilişkin esaslar tebliği, Seri: VII, No: 10 (09/02/2013 tarihli ve 28702 sayılı Resmi Gazete), http://www.spk.gov.tr/apps/Mevzuat adresinden 17.08.2016 tarihinde edinilmiştir.

Yolsal, H. (2012). A tipi yatırım fonlarının performansı: Banka ve aracı kurum fonları üzerine bir inceleme. Marmara Üniversitesi Iktisadi ve Idari Bilimler Fakültesi Dergisi, 32 (1), 343-364.

http://www.spk.gov.tr/apps/MutualFundsPortfolioValues/FundsInfos.aspx?ctype=T\&submenuheader=0 (Erişim Tarihi, 25.04.2016).

http://kap.gov.tr/yatirim-fonlari/faal-yatirim-fonlari.aspx (Erişim tarihi, 04.05.2016).

https://www.yapikredi.com.tr/yatirimci-kosesi/fon-bilgileri/YFAE2.aspx (Erişim Tarihi, 25.04.2016).

http://www.hsbc.com.tr/tr/portfoy/yatirim_fonlari/_pdf/FonBultenFiles/FonBulten-BIST30-endeksli-hisse-senedi.pdf (Erişim Tarihi, 25.04.2016).

http://www.ist30.com/sayfa/bist-30-endeksi (Erişim Tarihi, 25.04.2016).

http://www.garanti.com.tr/tr/bireysel/mevduat_ve_yatirim/yatirim_fonlari/hisse_agirlikli_fonlar.page, (Erişim Tarihi, 25.04.2016).

http://tr.investing.com/indices/ise-30-historical-data (Erişim Tarihi, 25.04.2016).

http://www.akportfoy.com.tr/tr/fund/ADP (Erişim Tarihi, 02.05.2016).

http://www.spk.gov.tr/yayingoster.aspx?yid=939\&ct=f\&action=displayfil (Erişim Tarihi, 23.06.2016).

http://www.tcmb.gov.tr (Erişim Tarihi, 24.06.2016).

http://www.tcmb.gov.tr/wps/wcm/connect/TCMB+TR/TCMB+TR/Main+Menu/Istatistikler/Piyasa+Verileri/ihale+Yont emi+ile+Satilan+Hazine+Bonolari+ve+Devlet+Tahvilleri/ (Erişim Tarihi, 24.06.2016). 


\section{Ekler}

EK 1. Bir Aylık Veri Seti Örneği

\begin{tabular}{|c|c|c|c|c|c|c|c|c|c|}
\hline Tarih & VEF & $\mathrm{HBU}$ & TIE & GAE & AKU & YEF & TZE & BIST 30 & DiBS \\
\hline 01.12 .2015 & 0.301 & 0.066 & 0.038 & 0.023 & 0.046 & 0.045 & 0.021 & 94146.6 & 0.36 \\
\hline 02.12 .2015 & 0.307 & 0.067 & 0.039 & 0.024 & 0.047 & 0.046 & 0.021 & 93606.9 & 0.36 \\
\hline 03.12 .2015 & 0.305 & 0.067 & 0.039 & 0.024 & 0.047 & 0.045 & 0.021 & 92452.8 & 0.36 \\
\hline 04.12 .2015 & 0.301 & 0.066 & 0.038 & 0.023 & 0.046 & 0.045 & 0.021 & 90901.6 & 0.36 \\
\hline 07.12 .2015 & 0.297 & 0.065 & 0.038 & 0.023 & 0.045 & 0.044 & 0.020 & 90544.8 & 0.36 \\
\hline 08.12 .2015 & 0.296 & 0.065 & 0.037 & 0.023 & 0.045 & 0.044 & 0.020 & 89595.1 & 0.36 \\
\hline 09.12 .2015 & 0.293 & 0.064 & 0.037 & 0.023 & 0.045 & 0.044 & 0.020 & 91587.3 & 0.36 \\
\hline 10.12 .2015 & 0.299 & 0.066 & 0.038 & 0.023 & 0.046 & 0.044 & 0.021 & 88772.0 & 0.36 \\
\hline 11.12 .2015 & 0.291 & 0.064 & 0.037 & 0.023 & 0.044 & 0.043 & 0.020 & 86196.1 & 0.36 \\
\hline 14.12 .2015 & 0.283 & 0.062 & 0.036 & 0.022 & 0.043 & 0.042 & 0.020 & 84893.1 & 0.36 \\
\hline 15.12 .2015 & 0.279 & 0.061 & 0.035 & 0.022 & 0.042 & 0.041 & 0.019 & 88583.3 & 0.36 \\
\hline 16.12 .2015 & 0.290 & 0.063 & 0.037 & 0.023 & 0.044 & 0.043 & 0.020 & 89380.1 & 0.36 \\
\hline 17.12 .2015 & 0.293 & 0.064 & 0.037 & 0.023 & 0.045 & 0.043 & 0.020 & 90427.3 & 0.36 \\
\hline 18.12 .2015 & 0.296 & 0.065 & 0.037 & 0.023 & 0.045 & 0.044 & 0.020 & 88788.1 & 0.36 \\
\hline 21.12 .2015 & 0.291 & 0.064 & 0.037 & 0.023 & 0.044 & 0.043 & 0.020 & 89848.0 & 0.36 \\
\hline 22.12 .2015 & 0.294 & 0.064 & 0.037 & 0.023 & 0.045 & 0.044 & 0.020 & 89411.8 & 0.36 \\
\hline 23.12 .2015 & 0.293 & 0.064 & 0.037 & 0.023 & 0.045 & 0.043 & 0.020 & 90567.1 & 0.36 \\
\hline 24.12 .2015 & 0.296 & 0.065 & 0.037 & 0.023 & 0.045 & 0.044 & 0.020 & 90583.0 & 0.36 \\
\hline 25.12 .2015 & 0.296 & 0.065 & 0.037 & 0.023 & 0.045 & 0.044 & 0.020 & 90751.8 & 0.36 \\
\hline 28.12 .2015 & 0.297 & 0.065 & 0.037 & 0.023 & 0.045 & 0.044 & 0.020 & 90785.3 & 0.36 \\
\hline 29.12.2015 & 0.297 & 0.065 & 0.037 & 0.023 & 0.045 & 0.044 & 0.020 & 90361.0 & 0.36 \\
\hline 30.12 .2015 & 0.296 & 0.065 & 0.037 & 0.023 & 0.045 & 0.044 & 0.020 & 89378.9 & 0.36 \\
\hline 31.12 .2015 & 0.293 & 0.064 & 0.037 & 0.023 & 0.044 & 0.043 & 0.020 & 87428.5 & 0.36 \\
\hline
\end{tabular}

Not. Tabloda 2015 yılının son ayına ait yatırım fonu birim pay değerleri, BisT 30 endeksi günlük kapanış değerleri ve ilgili ayın günlük ortalama DiBS faiz oranı verisi yer almaktadır. 
This Page Intentionally Left Blank 